\title{
Turgut Özal Döneminde Türkiye’nin Ortadoğu Politikalarının Liberalizm Çerçevesinden İncelenmesi (1983-1993)
}

Ferhat Durmaz*

\section{Öz}

Bir uluslararası ilişskiler teorisi olarak liberalizm, devletlerin uluslararası ilişkilere yönelik bakış açısının şekillenmesinde ulusal dinamiklerin etkili olacağını ve iki devlet arasındaki iliş̧kilerde ortak çıkarların söz konusu olması halinde işbirliğinin tesis edileceğini belirtmektedir. Turgut Özal, ihracatı teşvik eden 24 Ocak kararlarının etkisiyle Ortadoğu'ya yönelik politikada ekonomik işbirliğini geliştirmeyi ve ekonomik işbirliği projeleri aracılığıyla ikili sorunları çözmeyi ve bölgesel barışa katkı sağlamayı hedeflemiştir. Irak-Iran savaşı süresince Özal liderliğindeki Türkiye ile Ortadoğu ülkeleri arasında ortak çıkarların varlığı nedeniyle bir işbirliği ortamı tesis edilmiştir. Bu dönemde Türkiye ile Ortadoğu ülkeleri arasında ticari alanda belli düzeyde bir karşıııkı bağımlılık olmuş ve bu bağımlıı̆̆ın etkisiyle taraflar sorunları çözmeye yönelik adım atmışlardır. Bununla birlikte, Irak-ïran savaşının sona ermesini takip eden süreçte, Türkiye ile Ortadoğu ülkeleri arasında ortak çıkarların tesis edilememesi ve tarafların meseleleri farklı değerlendirmeleri işbirliği ortamının zarar görmesine neden olmuştur. Bu çalışma, liberalizm çerçevesỉnde, Turgut Özal döneminde Türkiye'nin Ortadoğu politikasına yön veren faktörleri, politikaların genel görünümünü ve uygulama boyutunu incelemeyi amaçlamaktadır.

Anahtar Kelimeler: Liberalizm, Turgut Özal, Ortadoğu, Ekonomik İşbirliği ve Ortak Çıkar.

An Analysis on Turkey's Middle East Policy during Turgut Özal Period within the Framework of Liberalism (1983-1993)

\section{Abstract}

As a theory of international relations, liberalism states that national dynamics will be effective in shaping the perspective of states, and cooperation will be established if there are common interests in relations between the two states. Turgut Özal aimed to develop economic cooperation in policy towards the Middle East, solve bilateral problems through economic cooperation projects and contribute to regional peace. During the Iraq-Iran war, cooperation was established between Turkey and the Middle Eastern countries due to the existence of common interests. During this period, there was a certain level of mutual dependency in the commercial field between Turkey and the Middle Eastern countries, and the parties took steps to solve the problems. After the Iraq-Iran war, the inability to establish common interests between Turkey and the Middle Eastern countries caused the environment of cooperation to be damaged. This study aims to examine the Middle Eastern policies of Turkey during Özal period within the framework of liberalism.

Keywords: Liberalism, Turgut Özal, Middle East, Economic Cooperation and Common Interest.

*Dr. | ferhatdurmaz2013@gmail.com | ORCID: 0000-0002-1315-7686 DOI: 10.36484/liberal.913034

Liberal Düşünce Dergisi, Yıl: 26, Sayı:103, Yaz 2021, ss.205-236.

Gönderim Tarihi: 10 Nisan 2021 | Kabul Tarihi: 16 Eylül 2021 


\section{Giriş}

Liberalizm, realizm gibi uluslararası sistemin anarşik bir yapıda olduğunu kabul etmekte ancak realizmden farklı olarak anarşinin mutlak ve kaçınılmaz bir durum olmadığını iddia etmektedir. Liberalizme göre, devletlerarası ilişkilerin ortak çıkarlar temelinde gelişmesi ve uluslararası alanda uluslararası hukuk ile uluslararası örgütlerin varlığı ve getirdiği yasal düzenlemeler uluslararası sistemin anarşik niteliğinin zayıflamasında etkili olmaktadır. Liberalizm, iki devlet arasında ekonomi alandaki ortak çıkarların siyasi sorunların çözülmesinde veya siyasi sorunların belli bir süreliğine ikinci planda kalmasında işlevsel bir rol oynayacağını belirtmektedir. Liberalizm, devletlerin uluslararası ilişkilere yönelik bakış açısının şekillenmesinde rejim tiplerinin ve liderlerin algılamaları gibi daha çok ulusal dinamiklerin belirleyici olacağını ileri sürmektedir. Anlaşmalar, projeler ve diplomasi gibi yumuşak güç unsurlarına önem veren liberalizm, liberal devletlerin zaman zaman diğer devletlere karşı sert güç unsurlarını kullanabileceğine dikkat çekmektedir.

Liberalizmin görüşlerinden hareketle, makale, 1980'li yıllarda ve 1990'ların ilk yıllarında Türkiye'nin Ortadoğu politikasının genel niteliğinin belirlenmesinde ulusal alandaki gelişmelerin etkili olduğunu vurgulamaktadır. Lider düzeyinde, Başbakanlık (1983-1989) ve Cumhurbaşkanlığı (1989-1993) görevinde bulunduğu süre boyunca Turgut Özal, Türkiye’nin bölgesel sistemde ve uluslararası ilişkilerde etkin bir aktör haline gelmesi için vizyoner bir Ortadoğu politikası konması gerektiğini savunmuştur. Özal, Türkiye'nin Ortadoğu politikasını şekillendiren ulusal, tarihsel ve kültürel faktörlere dış politikanın yürütülme sürecinde işlevsel bir rol kazandırmaya çalışmıştır.

Çalışma, Türkiye'nin ekonomik büyümesinde dış ekonomik ilişkileri güçlendirmenin önemli olduğu görüşünden hareketle Özal'ın Ortadoğu ülkeleri ile ekonomik ilişkilerin geliştirilmesine özel bir önem verdiğini ve ekonomik ilişkilerin geliştirilmesi yoluyla siyasi ve güvenlik sorunlarını çözmeyi hedeflediğini belirtmektedir. Özal'ın ekonomi üzerinden bölge ile ilişkilerin güçlendirilmesi ve bu yolla sorunların çözülmesi yaklaşımı, Türkiye ile Ortadoğu ülkeleri arasındaki ilişkilerde Irak-İran savaşı (1980-1988) süresince uygulamaya aktarılan bir nitelikte olmuştur. Irak-İran savaşı boyunca Ortadoğu ülkelerinin Türkiye ile ilişkileri geliştirmeye ihtiyaç duymaları nedeniyle ikili sorunlar gündeme getirilmemeye çalışılmış ve ilişkilerde işbirliği ile uzlaşıya dayalı bir politik hava hâkim olmuştur. Bununla birlikte, Türkiye ile Ortadoğu ülkeleri arasında ortak çıkarlar tesis edilemediği durumlarda sorunlar daha görünür bir nitelik kazanmıştır. 
Bu genel çerçeve dahilinde, çalışma, Özal döneminde Türkiye'nin Ortadoğu politikasını liberalizm çerçevesinden incelemeyi amaçlamaktadır. Çalışma, öncelikle liberalizmin uluslararası ilişkilerle ilgili temel argümanlarını analiz edecektir. Daha sonra, çalışmada Turgut Özal'ın Ortadoğu politikasının oluşumu ve bu politikanın temel ilkeleri liberal teorinin görüşleri çerçevesinde ortaya konacaktır. Devam eden kısımda, Özal'ın perspektifinin uygulama boyutu farklı başlıklar altında hedef-sonuç bağlamında irdelenecektir. Sonuç bölümünde, Özal'ın politikalarının vizyon ve pratik boyutuna ilişkin tespitlerde bulunulacaktır.

\section{Liberalizm ve Uluslararası İlişkiler}

Batı siyasi geleneğini şekillendiren en güçlü ideolojilerden birisi olan liberalizm; John Locke, Adam Smith, Immanuel Kant, Jeremy Bentham, John Stuart Mill ve John Rawls olarak sıralanabilecek filozofların görüşleri çerçevesinde devletin sınırlandırılması gerektiğini savunan, anayasa, demokrasi, insan hakları ve hukukun üstünlüğü şeklindeki unsurların önemini vurgulayan ve bireysel özgürlüğü ön plana çıkaran bir ideolojidir. Liberalizm, rasyonalizm çerçevesinde ilerlemeyi öngörmekte ve ekonomide serbest piyasaya öncelik verirken devlet müdahalesini kabul etmemektedir. Liberalizmin bir uluslararası ilişkiler teorisi olarak temel argümanları şu şekilde analiz edilebilir:

Liberalizm, realizm gibi uluslararası alanın anarşik bir yapıda olduğunu kabul etmektedir. Realizmden farklı olarak, liberalizm uluslararası ilişkilerde anarşik bir ortam hâkim olsa da devletlerin kendi aralarında bir işbirliği geliştirebileceğini öngörmektedir (Russett, 2013). Anarşinin hâkim olduğu uluslararası sistemde uluslararası örgütler ile kurumların varlığı devletler arası ilişkilerde işbirliğinin tesis edilmesini mümkün kılmaktadır. Bir diğer husus, realizmin insanın doğası gereği çatışmayı öncelik haline getiren bir tutumda olacağı görüşünün aksine (Hobbes, 1998), liberalizmin insanların rasyonel bir şekilde hareket ederek iyi ve doğru olana ulaşabileceğini belirtmesidir (Locke, 1980). İyi ve doğru olanı arama anlayışı içerisinde olan insan erdemli bir davranış göstererek, barışı öncelik haline getirecek ve savaştan uzak durma eğiliminde olacaktır (Gradner, 1990: 23-39). Ayrıca, realizmin uluslararası ilişkilerin güce dayalı askeri unsurlar çerçevesinde işleyeceği argümanının aksine liberalizm uluslararası ilişkilerde ahlaki temaların ve kuralların en az güç unsurları kadar önemli bir yer tutacağını belirtmektedir (Bentham, 2009; Keohane, 1990: 165-194). Bu çerçevede liberalizmin uluslararası ilişkilere normatif bir bakış açısı getirdiği söylenebilir. Liberalizm, uluslararası hukuk normlarının uygulamaya aktarılmasını, insan haklarının 
tesisini ve insani güvenliğin sağlanmasını uluslararası ilişkilerde barış ve istikrarın sağlanmasında son derece elzem görmektedir (Rawls, 1999).

Liberalizm, bir devletin ulusal sistemde nasıl yönetildiğinin ve ekonomi alanında benimsediği modelin uluslararası ilişkilere yönelik bakış açısının şekillenmesinde önemli bir rol oynayacağını iddia etmektedir (Kant, 1983; Paine, 1995). Örneğin, bir devlet sınırları içerisinde insan haklarının üstünlüğünü ya da serbest piyasa ekonomisinin gelişmesini öncelik haline getirdiyse, o devletin uluslararası ilişkilere yönelik bakış açısında insan hakları gibi normatif değerler ve ihracat ile ithalatın serbestleştirilmesi gibi küresel piyasaya entegre olma yönündeki davranışlar ön plana çıkacaktır. Liberalizmin ulusal boyutu ön plana çıkarması uluslararası dinamikleri tamamen göz ardı ettiği anlamına gelmez. Liberalizm, devletlerin uluslararası ilişkilere yönelik bakış açısının şekillenmesinde diğer aktörlerin geliştireceği dış politika davranışlarının etkili olacağını belirtmektedir (Moravcsik, 1992: 11-13). Örneğin, bir devlet, s1nır komşusu kendisine yönelik düşmanca bir tutum ortaya koyması ve askeri araçları kullanması halinde kendisi de askeri araçları tercih edebilecektir.

Liberalizm, uluslararası ilişkilerde devletlerin salt ulusal çıkarlarından ziyade ortak çıkarların belirleyici olacağını ve iki devlet arasındaki işbirliğinin ortak çıkar olgusunun geçerli olduğu bir durumda ortaya çıkacağını belirtmektedir (Haas, 1980: 357-406; 1987). Devletler arası ilişkilerde ortak çıkarların olması halinde çıkar çatışmasına dayalı politik eylemlerin yerine normlara, kurallara, ticarete, işbirliğine ve barışa dayalı bir politik hava hâkim olacaktır (Rosecrance, 1986). Dolayısıyla, bir devlet, uluslararası ilişkilerde diğer devletlerle geliştirdiği ilişkilerin işbirliği niteliği kazanması için salt kendi ulusal çıkarlarını öncelik haline getirmenin ötesinde diğer devletlerin de çıkarlarını dikkate almanın önemli ve gerekli olduğunu bilmektedir. Devletler arasında ortak çıkarlara dayalı işbirliği aynı zamanda süreklilik kazanan bir nitelikte olacaktır.

Diğer yandan, liberal devletler uluslararası alanda birtakım eylemler ortaya koyarken olumlu sonuçlar elde etmeyi öncelik haline getirmektedir. Liberal devletler, en kısa sürede hangi yöntemin istenen sonucu vereceği düşünüyorlarsa o yöntemi tercih etmekte ve kararları rasyonel bir şekilde hareket ederek almaktadır. Liberal devletler, uluslararası ilişkilerde geliştirdikleri eylemlerle insan haklarını korumayı, demokratik normları güçlendirmeyi, piyasa ekonomisinin kapsamı ile etkinliğini artırmayı, liberal demokratik ülkeler arasında ilişkileri güçlendirmeyi ve uluslararası barış ile güvenliği sağlamayı hedeflemektedirler (Starr, 2007: 35). 
Karar alma süreci açısından incelediğimizde, liberalizm, devlet içerisindeki bireylerin, bürokrasinin, kamuoyu ile çıkar gruplarının karar alma sürecini etkileyeceğini varsaymaktadır (Moravcsik, 2001: 5-9). Liberal devletlerin demokratik ya da cumhuriyetçi bir nitelikte olması devlet içerisindeki çeşitli aktörlerin uluslararası ilişkileri ilgilendiren bir meselede kendi görüşlerini ifade edebilmesine, bu görüşü savunabilmesine ve dış politika kararının içeriğinin şekillenmesinde önemli bir rol oynayabilmesine olanak sağlamaktadır (Kaarbo, 2015: 8). Bu niteliğiyle, liberalizme göre, dış politika kararları yasal sürece dâhil olan devlet içerisindeki çeşitli aktörler arasındaki bir uzlaşının sonucu olarak ortaya çıkabilmekte ya da süreçte diğer aktörler karşısında üstünlük kazanan bir aktörün görüşleri çerçevesinde şekillenebilmektedir (Kaarbo, 2015: 9).

Liberalizm, devletlerin uluslararası ilişkilere yönelik yaklaşımlarında askeri araçlardan ziyade diplomasiye, yasal düzenlemelere ve uluslararası örgütler gibi çok taraflı kurumlara başvuracaklarını belirtmektedir (Ruggie, 1993). Bunun temel nedeni devletlerin sahip oldukları demokratik değerlerin, meşruluğu daha fazla olan araçları kullanmayı daha öncelikli kılmasıdır. Örneğin, bir sert güç unsuru olan savaş ile kıyaslandığında diplomasi, devletlerin eylemlerinin hem uluslararası alanda diğer devletler karşısında hem de ulusal sistemde toplumun nezdinde daha fazla kabul görmesini sağlayacak bir araçtır. Tersi bir bakış açısıyla, devletler askeri gücü tercih etmeleri halinde hem kendi toplumlarının eleştirisine maruz kalabilecek hem de uluslararası ilişkilerde saldırgan bir tutum izlemekle suçlanacaklardır. Bir diğer neden, devletlerin işbirliği, barışçıl ilişkiler ve ekonomik kazanç şeklindeki hedeflerinin çok taraflı kurumlar çerçevesinde uygulamaya aktarılmasının daha meşru ve etkili olacağıdır.

Bu genel çerçevenin yanında Robert O. Keohane (1990: 165-194) liberalizmin uluslararası ilişkilere yönelik bakış açısının cumhuriyetçi liberalizm (republican liberalism), ticari liberalizm (commercial liberalism), düzenleyici liberalizm (regulatory liberalism) ve sosyolojik liberalizm (sociological liberalism) olarak dört alt başlıkta incelenebileceğini belirtmektedir:

\section{Cumhuriyetçi Liberalizm}

Immanuel Kant'ın (1983 ve 1991) görüşleri çerçevesinde şekillenen cumhuriyetçi liberalizme göre, devletlerin iç siyasal sistemlerinin demokratik bir yapıda olmaması dış politikalarında işbirliği ve barış gibi temaların daha az yer tutmasını beraberinde getirmekte ve devletler arası ilişkilerin görüş ayrılığı, rekabet, çatışma ve savaş gibi unsurlar çerçevesinde ilerlemesi ihtimalini 
artırmaktadır. Dolayısıyla, cumhuriyetçi liberalizm, devletlerin cumhuriyetçi ve demokratik esaslara göre yönetilmesinin uluslararası ilişkilerde işbirliğinin gelişimi ve barışın sağlanması konusunda işlevsel bir rol oynayacağını belirtmektedir (Kant, 1983). Cumhuriyetçi liberalizmin savunduğu demokratik barış teorisi (democratic peace theory), uluslararası ilişkilerde demokratik devletlerin birbirleriyle savaşma ihtimallerinin düşük düzeyde olduğunu belirtmektedir (Kant, 1983). Bunun nedeni, demokratik devletlerin benimsemiş oldukları uzlaşı, anlaşma, müzakereye öncelik verme gibi yöntemlerin uluslararası ilişkilere yönelik bakış açılarında barış̧̧ıl bir yaklaşımı egemen kılacakları savıdır. Bir diğer neden, bir ülkenin rejimi demokratik bir nitelik gösteriyorsa o devletin savaşa başvurma olasılığı azalmaktadır çünkü demokratik devletler şiddetin ve savaşın kendileri için iyi/olumlu bir erdem olmadığının, savaşın maliyetler getirmesi nedeniyle halka hesap vermek zorunda kalacaklarının ve rasyonel politikalar sayesinde işbirliği ile barışın tesis edileceğinin farkındadırlar (Kant, 1991: 99-100). Bu noktadan hareketle, cumhuriyetçi liberalizm devletlerin benimsemiş oldukları rejimin/yönetim şeklinin uluslararası ilişkilerin anarşik niteliğinin zayıflamasında etkili olacağını söylemektedir.

\section{Ticari Liberalizm}

Ticari liberalizme göre, devletler arasındaki ekonomik ilişkiler serbest ticaret çerçevesinde yürütülüyorsa, devletler serbest ticaretten elde ettikleri kazançları sürdürme eğiliminde olacaklar ve ekonomik kazancın getirdiği faydanın etkisiyle savaştan ziyade barışı tercih edeceklerdir (Paine, 1995; Smith, 2009). Ticari liberalizm, iki devletin birbirleriyle olan ilişkilerinde ekonomik çıkarlara önem vermesi halinde bunun sadece ekonomi alanında karşılıklı çıkarlara değil aynı zamanda siyasi alanda olumlu sonuçlara yol açacağını öngörmektedir (Howard, 2008). Örneğin, siyasi konularda aralarında belli sorunlar bulunan iki devlet ekonomik işbirliğine gittiği takdirde bu iki devlet ekonomi işbirliğini koruma gerekçesiyle çatışma konularını belli bir süreliğine ikinci plana itme ve çeşitli sorunlar karşısında birbirlerini anlama eğiliminde olacaklardır. Bu noktadan hareketle, ticari liberalizmin siyaset ve ekonomi arasındaki ilişkide ekonomiyi siyaset karşısında geri planda konumlandırmaktan ziyade ekonomiyi siyaseti şekillendiren bir faktör olarak gördüğü söylenebilir (Gilpin, 1987: 26-31). Ekonominin siyaset karşısında öncelikli olarak görülmesi devletlerin uluslararası ilişkilerde siyasi sorunları tekrarlamaktan ya da yeni siyasi sorunların oluşmasına neden olmaktan ziyade temelde ekonomik kazanç sağlama motivasyonuyla hareket edecekleri şeklindeki bakış açısının bir sonucudur. 
Diğer yandan, David Ricardo (1911), devletler arası ekonomik ilişkilerin 'karşılaştırmalı üstünlük (comparative advantage)' olarak kavramsallaştırdığı bir bakış açısı çerçevesinde işleyeceğini iddia etmiştir. Bu bakış açısına göre, devletler kendilerinin üstün olduğu ticari malı karşı tarafa satarken görece dezavantajlı olduğu ticari malı satın alma yoluna gideceklerdir. Ricardo’ya göre (1911: 114), 'karşılaştırmalı üstünlüğe' dayalı bu ticaret anlayışı devletleri ekonomik çıkar bağı çerçevesinde bir araya getirecektir.

\section{Düzenleyici Liberalizm}

Düzenleyici liberalizm, uluslararası örgütlerin ve uluslararası hukukun devletler arası ilişkilere yönelik getirdiği düzenleyici normların devletleri barışçıl ilişkilere ve işbirliğine teşvik edeceğini aynı zamanda onların askeri çatışma ve savaş gibi unsurlardan uzak durmalarına yol açacağını söylemektedir (Rawls, 1999: 11-23). Uluslararası örgütler ve uluslararası hukuk öngördüğü yöntemlerle ve ortaya koyduğu kurallarla devletlerin davranışlarına yönelik belli sınırlamalar getirmektedir (Moravcsik, 1992; Rawls, 1999). Örneğin, savaş, bir devletin istediği zaman başvurabileceği bir araç olmaktan ziyade meşru müdafaa çerçevesinde düşünebileceği bir yöntem haline gelmektedir. Benzer şekilde, uluslararası alanda anlaşmazlıklar uluslararası örgütler ya da uluslararası hukuk çerçevesinde tesis edilen hakemlik merci ve uzlaştırma mekanizmaları gibi çeşitli yöntemler aracılığıyla barışçıl bir şekilde çözülebilmektedir.

\section{Sosyolojik Liberalizm}

Sosyolojik liberalizm, bir devletin içerisinde yer alan insanların ve toplumların algılamalarının, bakış açılarının ve eylemlerinin uluslararası ilişkileri etkileyebileceğini savunmaktadır (Keohane, 1990; Jackson, Sorensen, Moller, 2018). Örneğin, bir devleti yöneten liderlerin diğer aktörlere yönelik bakış açılarının olumlu yönde değişmesi devletler arası ilişkilerdeki sorunların çözülmesinde ya da bu ilişkilerde işbirliğinin tesis edilmesinde etkili olabilmektedir. Benzer şekilde, toplumlar arasındaki engellerin kaldırılmasıyla insanlar birbirleriyle daha fazla etkileşime girmekte, etkileşimde bulunurken birbirlerinin kimlik ve değerlerine saygı gösterebilmekte ve bu etkileşim ile saygı olumsuz durumları engelleyebilmektedir (Jackson, Sorensen, Moller, 2018). Toplumlar arasındaki ilişkilerin olumlu yönde olduğu bir politik ortamda liderler birbirlerine karşı hamasi bir tutum içerisinde olsalar bile toplumu bu düşmanca tutum lehine mobilize etme imkânları azalmaktadır (Sorensen, 2006: 251-272). 
Diğer yandan, liberalizm uluslararası ilişkilerde barışın sağlanabileceğini belirtmesine rağmen zaman zaman hem liberal devletler hem de liberal olmayan devletlerin tutumundan kaynaklı olarak uluslararası ilişkilerde güç unsurları gündeme gelebilmekte ya da işbirliği ortamı tesis edilememektedir. David Hume’un (1963: 346-347) ‘düşüncesizce sertlik (imprudent vehemence)' olarak tanımladığı durum, cumhuriyetçi ya da demokratik sistemle yönetilen devletlerin çeşitli hedeflere ulaşmak için savunma yönü ağır basan savaşlara başvurmasının yanında diğer devletlere yönelik askeri müdahaleyi, politik baskııı ve muhaliflerin finanse edilmesi şeklindeki yöntemlere başvurabileceğini ifade etmektedir. Liberalizme göre, işbirliğinin önündeki bir diğer önemli engel, bir aktörün ortaya koyduğu işbirliği perspektifinin diğer aktörler tarafından kendi egemenliklerine ve çıkarlarına zarar verecek bir girişim olarak değerlendirilmesidir (Burchill, 2005).

\section{Turgut Özal'ın Ortadoğu Vizyonu}

Liberalizmin bir devletin ulusal sistemdeki temel dinamiklerinin ve ekonomi alanında benimsediği modelin uluslararası ilişkilere yönelik bakış açısının şekillenmesinde önemli bir rol oynayacağı düşüncesi (Kant, 1983; Paine, 1995), 1980'lerde Türkiye’nin Ortadoğu'ya yönelik yaklaşımında görülmüştür. Bu dönemde, ulusal sistemde Turgut Özal'ın ekonomi ve dış politika konusundaki bakış açısı Türkiye'nin Ortadoğu politikasının yeniden tanımlanmasına yol açmıştır.

Turgut Özal, 1983’te Başbakan olmadan önce, kamuda Devlet Planlama Teşkilatı, özel sektörde Sabancı Holding ve uluslararası alanda Dünya Bankası Sanayi Dairesi gibi kurumlarda ekonomik niteliği ağır basan çeşitli görevlerde bulunmuş bir liderdir. Özal'ın hem bürokraside hem de özel sektörde çeşitli görevler üstlenmesi onun ekonomik hayatı ve Türkiye'nin sorunlarını daha yakından tanımasına olanak sağlamıştır. Özal, 1970’lerde izlenen ithal edilen ürünlerin Türkiye sınırları içerisinde benzerlerinin üretilmesine dayalı ithal-ikameci sanayileşmenin ve devletin müdahalesini öngören ekonomik anlayışın Türkiye ekonomisinin büyümesi sürecinde yetersiz kaldığını düşünmekteydi. Özal'ın bu düşüncesi Türkiye ekonomisine radikal değişiklikler getiren 24 Ocak 1980 kararlarının alınmasına yol açtı. Devlet mekanizmasının ekonomideki payını küçültmeyi amaçlayan ve fiyatlara yönelik müdahalelerin kaldırılarak serbest piyasa ekonomisine geçilmesini öngören 24 Ocak kararları Türkiye'nin dış ekonomik ilişkilerine ilişkin üç radikal değişiklik getirmekteydi: (i) dış ticaretin serbestleştirilmesi; (ii) yabancı sermaye yatırımlarının sermaye ve hizmet akışına kolaylık sağlanarak teşvik edilmesi; 
(iii) ihracatın vergi iadesi ve düşük faizli kredi gibi çeşitli yöntemlerle desteklenmesi. Dolayısıyla, Özal, uluslararası ekonomiyle bütünleşmenin ithal-ikameci sanayileşme ile kıyaslandığında Türkiye ekonomisinin dinamizm kazanmasında daha etkili bir yöntem olacağını öngörmekteydi (Özal, 1985: 247-248; Duman, 2011: 118).

24 Ocak kararları çerçevesinde Özal liderliğinde Türkiye, 1980-1983 arası dönemde belli ölçüde ve 1983'ten sonra yoğun bir şekilde, ekonomi merkezli bir dış politika yaklaşımı benimsedi. Özal, Türkiye'nin dış politikada Ortadoğu ülkeleriyle ilişkilerinde serbest ticareti tesis etmesini, ihracatı kolaylaştırmaya yönelik çeşitli anlaşmalar imzalamasını ve ekonomik işbirliğine dayalı çeşitli örgütler kurmasını hedeflemekteydi (Aral, 2001: 76). Bunun nedeni ekonomik ilişkilerin güçlenmesinin Türkiye'ye sermaye akışını sağlayarak Türkiye ekonomisinin büyümesinde etkili olacağının düşünülmesiydi. Diğer bir neden, 12 Eylül 1980 darbesi nedeniyle Avrupa Topluluğu ile ilişkilerin durağan bir görünüm sergilediği bir dönemde Türkiye için Ortadoğu bölgesindeki ülkelerle ekonomik ilişkileri çeşitlendirmenin öneminin ortaya çıkmasıydı. Ayrıca, Özal, Türkiye ile Ortadoğu ülkeleri arasında ekonomik işbirliğinin gerçekleşmesi halinde, bu işbirliğinin Türkiye ile bölge arasındaki bağların olumlu yönde güçlenmesine yol açacağını düşünmekteydi (Ataman, 2003: 54).

Ticari liberalizmin ekonomik ilişkilerin gelişmesiyle siyasi sorunların ikinci planda kalacağı ve tarafların ticari ilişkileri sürdürmek gerekçesiyle işbirliğini devam ettirecekleri ve barışı tercih edecekleri varsayımı (Paine, 1995), Özal'ın Ortadoğu'ya yönelik politikasında önemli bir yer tutmuştur. Özal, Türkiye ile Ortadoğu ülkeleri arasındaki ilişkilerde ekonomi alanında güçlü olumlu çlktılar elde edilmesi yoluyla güvenlik ve siyasi alandaki sorunların çözülmesini ya da en azından tarafların birbirlerini anlayarak çözüme yönelik adımların atılmasının kolaylaşmasını hedeflemekteydi (Yavuzalp, 1996: 267). Dolayısıyla, Özal'ın Ortadoğu'ya yönelik ekonomi temelli yaklaşımının sadece ekonomi alanında kazançlar sağlama hedefinden ibaret değildi. Özal, ekonomi-siyaset ilişkisinde, tıpkı ticari liberalizmin yaklaşımında görüldüğü gibi (Gilpin, 1987: 26-31), ekonomiyi siyaseti şekillendirecek bir faktör olarak görmekteydi. Özal, öngörülen ekonomik işbirliğini sadece ekonomik ürün alışverişi yani ihracat ve ithalat çerçevesinde şekillendirmemiş aynı zamanda ortaya koyduğu işbirliği girişimleriyle, örneğin Seyhan ve Ceyhan nehirlerinin sularını Suriye, Ürdün, Suudi Arabistan, Kuveyt, Bahreyn, Katar, Umman ve İsrail'e taşımayı amaçlayan Barış Suyu Projesiyle, bölge ülkeleri arasında yumuşak güç unsurları temelinde bir karşılıklı bağımlılık oluşturmayı hedeflemiştir (Ataman, 2002: 137). Ortadoğu ülkeleri arasında 
ortaya çıkacak karşılıklı bağımlılık ile Özal'ın iki dış politika çıktısı elde etmek istediği söylenebilir: (i) Türkiye ile sınır komşuları olan Irak ve Suriye arasında PKK ve su sorunu nedeniyle yaşanan uyuşmazlıkları gidermek; (ii) Ortadoğu devletleri ile İsrail arasında bir yumuşamanın tesis edilmesine zemin oluşturmak (Laçinok, 2007: 555).

Sosyolojik liberalizm, bir devletin içerisinde yer alan insanların algılamalarının ve bakış açılarının o devletin uluslararası ilişkiler perspektifini etkileyeceğini belirtmektedir (Keohane, 1990; Jackson, Sorensen, Moller, 2018). Sosyolojik liberalizm çerçevesinden değerlendirdiğimizde, Birinci Dünya Savaşı sırasında Arapların Osmanlı Devleti’ne karşı isyan etmesi ve Türkiye'nin kültürel olarak Batıya ait olduğu dolayısıyla bölge ülkelerinden çok farklı olduğu şeklindeki düşünceler Türk karar alıcıların bir kısmında Ortadoğu’ya yönelik olumsuz algıların oluşmasına neden olmuştu. Bununla birlikte, Arap isyanları ve Türkiye ile Ortadoğu arasındaki aidiyet bağları konusunda Özal tamamen farklı fikirlere sahipti. Özal, Arap isyanlarının abartılmaması gerektiğini, Türkler ve Arapların dört yüz yıl boyunca barış içerisinde bir arada bulunduklarını ve her iki toplumun ortak kültürel değerler ile geleneklere sahip olduğunu ve en nihayetinde tüm bu hususların işbirliği için motive edici dinamikler olduğunu belirtmekteydi (Gözen, 2002: 233-268). Özal'ın Arap isyanları gibi olumsuz unsurlardan ziyade her iki taraf arasındaki tarihsel ve kültürel unsurlara atıf yapması Türkiye ile Ortadoğu arasındaki bağları yeniden canlandırmaya çalıştığını göstermekteydi. Türkiye ile Ortadoğu ülkeleri arasındaki olumlu noktalara değinerek Özal, Türkiye’nin Ortadoğu’ya yönelik politikalarının uygulama boyutunu kolaylaştırmak ve içerik yönünden politikaların zenginleşerek daha etkin bir nitelik kazanmasını istemiştir. Özal'ın Ortadoğu'ya yönelik pozitif yaklaşımı Türkiye'ye diş politikada Ortadoğu'yu ötekileştirmeden bölgeyle daha yakın ilişkiler tesis edilmesi noktasında yapıcı bir rol yüklemiştir.

Özal, Türkiye'nin Cumhuriyet döneminde benimsediği Kemalist modernleşme perspektifinin Türkiye'nin kültürel olarak Ortadoğu coğrafyasındaki halklar ile devletler arasında bir kopukluk oluşturduğunun farkındaydı (Aral, 2001: 74-75). Cumhuriyet'in kuruluşundan sonra, Kemalist anlayışın ortaya koyduğu Batılılaşmanın sadece bir modernleşme perspektifi olarak kalmayıp aynı zamanda dış politikayı şekillendiren temel unsurlardan birisi haline gelmesi Türkiye'nin Ortadoğu ülkeleriyle ilişkilerinin çok fazla gelişmemesine neden olmuştu. Bununla birlikte, Özal (1991: 345), ülkelerin farklı kültürleri bir arada taşıyabileceğini, farklı kültürlerin ülkeler için bir çatışmadan ziyade zenginlik unsuru olabileceğini ve uygulamada ülkelerin bu çeşitlilik temelinde davranışlar geliştirebileceğini düşünmekteydi. Bu nedenle, Özal, 
Cumhuriyet'in kuruluş döneminde ve daha sonraki dönemlerde bastırılan bir kültürel kimlik olan İslam’a daha fazla önem verdi (Yavuz, 2001: 35-36). Bir konuşmasında Özal, “...diğer İslam ülkeleriyle yakınlaşmamızın nedeni bu kardeş ülkelerle aramızda mevcut olan kültürel ve dini bağların varlığ1dır..." sözleriyle bu düşüncesini ifade etmiştir (Gözen, 2000: 124; Vurgular bana aittir). Dolayısıyla, Özal, İslam ülkelerinin çoğunlukta yer aldığı Ortadoğu'ya yönelik politikayı sadece ekonomik değil aynı zamanda kültürel çerçevede şekillendirmiştir. Bu noktadan hareket ederek, Özal'ın iki hedefe ulaşmak istediği söylenebilir: (i) Türkiye'nin Ortadoğu'ya yönelik aktif bir politika izlediği süreçte kültürel ve tarihi bağların bölge ülkeleriyle ilişkilerin geliştirilmesinde yapıcı bir rol oynaması. (ii) Türkiye'nin sahip olduğu/taşıdığı kültürel değerler çerçevesinde Ortadoğu ülkeleri ile geliştireceği ilişkiler aracılığıyla Batı dünyası nezdinde Türkiye'nin stratejik öneminin artması (Altunışık, 2009: 182). Özal'ın Türkiye ile Ortadoğu ülkeleri arasındaki dini değerlere vurgu yapan ve bu çerçevede bölgeye yönelik bir vizyon geliştiren bakış açısında İslami değerlere önem veren bir kişiliğe sahip olmasının etkili olduğunu göz ardı etmemek gerekir (Özdemir, 2014).

Liberalizmin karar alma sürecinde devlet içerisindeki bireylerin, bürokrasinin, kamuoyu ile çıkar gruplarının etkili olacağı ve kararların bu aktörler arasındaki uzlaşıdan ya da süreçte hâkim olan herhangi bir aktörün etkisiyle ortaya çıkacağı görüşü çerçevesinden incelendiğinde (Moravcsik, 2001: 5-9; Kaarbo, 2015: 8-9), Özal'ın ortaya koyduğu yasal düzenlemelerle süreçte baskın hale geldiği ve karar alma sürecini büyük ölçüde kendi tekelinde tuttuğu söylenebilir. Özal'a göre, genel olarak diş politikada özel olarak Ortadoğu’ya yönelik politikada Türkiye'nin aktif bir politika izleyememesinin ve olaylar karşısında seyirci konumunda kalmasının nedeni sorumluluk almaktan kaçınan dolayısıyla dış politikada statükocu perspektifin en güçlü savunucusu olan dışişleri bürokrasisiydi. Bu nedenle Özal, iktidarının ilk yıllarında çıkardığı iki önemli kararname ile Dışişleri Bakanlığı'nın yetkisinde bulunan birçok konuyu özellikle dış ekonomik ilişkileri Hazine ve Dış Ticaret Müsteşarlığı kurarak ona devretmesi gibi başka kurumlara ya da bakanlıklara devretti (Çakmak, 2013: 118-119). Yürürlüğe konulan yasal düzenlemeler Özal'ın dış politikada inisiyatif almaktan çekindiğini düşündüğü Dışişleri Bakanlığı'nın pozisyonunu sınırlandırdığını göstermekteydi. Bir diğer önemli husus, Özal'ın Dışişleri Bakanlığı için, 1983-1987 arasında görev yapan Vahit Halefoğlu dişında, bakanlık geleneğinden gelen ya da uluslararası ilişkiler formasyonuna sahip olan insanlardan ziyade daha çok ekonomist ve teknokrat niteliği ön planda olan insanları görevlendirmesiydi. İlginç olan nokta, Özal'ın dönem boyunca Dışişleri Bakanı Ali Bozer'in ABD ile yapılan 
toplantıya dahil edilmemesi gibi Dışişleri Bakanlarını bilinçli olarak dış politika sürecinden uzak tutmaya çalışmasıydı (Hürriyet, 1 Mart 1988). Dışişleri Bakanlığı'nın ya da Bakanların çok fazla etkinlik kazanmamasını sağlayarak Özal, Türkiye'nin Ortadoğu'ya yönelik politikaları da dâhil olmak üzere dış politikayı çoğunlukla kendi görüşleri ve yöntemleri çerçevesinde yürüttü. D1şişleri Bakanlığı'nın ya da Bakanların sürece çok dâhil edilmemesi Özal'ın olayları etkilemeye yönelik hızlı bir tutum geliştirilmesi düşüncesinin ve bir an önce karar alınması tavrının Türkiye'nin Ortadoğu politikalarının genel özelliği haline gelmesi demekti.

Liberalizmin devletlerin uluslararası ilişkilere yönelik bakış açısının şekillenmesinde ulusal dinamiklerin yanında uluslararası sistemdeki diğer aktörlerin geliştireceği tutumların etkili olacağı savı (Moravcsik, 1992: 11-13), Özal'ın Cumhurbaşkanlığı görevi boyunca (1989-1993) Türkiye'nin Ortadoğu'ya yönelik politikalarında görüldü. Özal, Soğuk Savaş'ın sona ermesiyle yeni bir dünya düzeninin oluşmaya başladığı yıllarda Türkiye’nin Ortadoğu'ya yönelik politikasını ABD’nin Ortadoğu ülkelerine yönelik tutumunu ve eylemlerini desteklemek olarak şekillendirmiştir. Özal'ın politika değişikliğinde iki dinamik etkili olmuştur: (i) Soğuk Savaş'ın bitmesi ve Irak'ın Kuveyt'i işgal etmesiyle Ortadoğu siyasetinin yeniden şekilleneceği öngörüsü; (ii) Ortadoğu siyasetinin değişmeye başladığı bir dönemde, Türkiye’nin olumlu sonuçlar elde etmek ya da olası olumsuz sonuçlarla karşılaşmamak için bölge gelişmelerine müdahil olması gerektiği şeklindeki düşünce (Gürbey, 2001). Bir diğer husus, ABD’nin Ortadoğu'da İran'ın radikal İslami akımlar çerçevesinde etkinlik kazanmasını engellemek için Türkiye'yi bölgede bir model olarak ön plana çıkarmasıdır (Aral, 2001: 77). Özal, Ortadoğu'da ABD'yi destekleyerek belli meselelerde örneğin Körfez savaşı sonrası Irak'ın geleceğine ilişkin politikalarda Türkiye'nin söz sahibi olmasını sağlamayı ve Türkiye'nin stratejik öneminin devam ettiğini Batı dünyasına göstermeyi hedeflemiştir. ABD’nin Irak’a yönelik askeri unsurları ön plana çıkardığı bir süreçte, Özal, petrol boru hatlarını kapatarak ticareti karşı tarafı caydırmak için bir araç olarak kullanmış ve askeri müdahale seçeneğini gündemine almıştır. Özal'ın Soğuk Savaş sonrası dönemdeki bu politikası, Soğuk Savaş'ın devam ettiği ve Başbakanlık görevinde bulunduğu dönemde (1983-1989) Türkiye'nin Ortadoğu'ya yönelik politikasında ekonomik çıkarlar elde etmesini ve ekonomik kazançlar aracılığıyla güvenlik sorunlarının üstesinden gelmesini amaçlayan dış politika perspektifinden farklılaşmıştır.

Özetlemek gerekirse, Özal ülke yönetiminde bulunduğu süre boyunca Türkiye’nin Ortadoğu politikasını etkileyen faktörleri yeniden değerlendirmiştir. Özal, ekonomi alanında 24 Ocak kararlarıyla bir dönüşümü gerçekleştirmiş, 
Türkiye ile Ortadoğu arasındaki olumlu bağların önemine dikkat çekmiş ve Türkiye'nin bölgede daha etkili olması için lider olarak aktif bir rol almış ve dış işleri bürokrasisini devre dışı bırakmıştır. Özal, Türkiye’nin Ortadoğu ülkeleriyle işbirliği tesis etmesiyle Türkiye'nin ikili ekonomik ilişkilerden kazanç sağlamasını ve PKK'nın etkinliğini sınırlayarak Türkiye'nin sınır güvenliğini sağlamayı hedeflemiştir. Dahası, Soğuk Savaş nedeniyle Türkiye'nin dış politikada statükoyu öncelik haline getirdiğini ve bunun yakın çevresi ile uluslararası alandaki etkinliğini sınırladığını düşünen Özal, Soğuk Savaşın bitmesiyle Türkiye'nin Ortadoğu'ya yönelik dış politikada ve uluslararası ilişkilerde daha güçlü bir vizyon geliştirmesi gerektiğini savunmuştur (Özal, 1992). Özal'ın politikasının uygulamaya yansımaları şu şekilde analiz edilebilir:

\section{Irak ve Suriye}

Ticari liberalizmin devletlerin serbest ticaretten elde ettikleri kazancın etkisiyle siyasi sorunları ikincil bir gündem maddesi haline getirecekleri ya da çözüme yönelik adım atacakları düşüncesi (Gilpin, 1987: 26-31; Paine, 1995), Özal'ın Irak ve Suriye'ye yönelik politikalarında görülmüştür. Özal, ekonomik ilişkilerin gelişmesiyle ve su sorununu çözmeyi amaçlayan projelerin de olumlu katkısıyla, Türkiye-Irak-Suriye ekseninde bir karşılıklı bağımlılık ya da en azından bir işbirliği ortamı oluşturmayı arzu etmiştir. Böylece, Özal, 1980'lerin ortalarından itibaren Doğu ve Güneydoğu Anadolu'da eylemler gerçekleştiren ve Irak ile Suriye'de yaşama alanı bulan PKK (açılımı; Partiya Karkerên Kurdistanê / Kürdistan İşçi Partisi) terör örgütüyle mücadelede Irak ve Suriye'nin desteğini almayı ya da en azından PKK sorununun ilişkilerde bir gündem maddesi olmaktan çıkmasını hedeflemiştir.

Liberalizmin, devletlerin uluslararası ilişkilerde yöntem olarak diplomasiyi ve yasal düzenlemeleri öncelik haline getireceği yaklaşımı (Ruggie, 1993), Özal'ın Irak ve Suriye'ye yönelik politikasında geçerlilik kazanmıştır. Özal, Irak ve Suriye'ye yönelik politikasında PKK konusunda diplomasiyi öncelik haline getirmiş, her iki ülke nezdinde girişimler yürütmüş ve Türkiye, Ekim 1984’te Irak ile güvenlik protokolü ve Mart 1985'te Suriye ile sınır güvenliği protokolü imzalanmıştır (Fırat ve Kürkçüoğlu, 2001). Irak ve Suriye ile imzalanan güvenlik protokolleri çerçevesinde Türkiye iki önemli çıktı elde etmiştir: (i) Türk Silahlı Kuvvetleri’nin Irak sınırının 5 km kadar içeri girmesini sağlayacak yasal zemin tesis edilmiştir; (ii) PKK'ya yönelik mücadelede Irak ile istihbarat alışverişi, teröristlerin sızmalarını önleyecek tedbirlerin alınması ve gerektiğinde teröristlere yönelik koordineli bir mücadele yapılması gibi yoğun düzeyde ve Suriye ile sınır geçişlerinin kontrol edilmesine ilişkin teknik 
konularda görüşmeler gerçekleştirilmesi gibi kısmi ölçekte bir işbirliği süreci oluşturulmuştur. Irak ile daha yüksek düzeyli bir işbirliği tesis edilmesinin nedeni, Irak-İran savaşının sürdüğü bir ortamda, Irak'ın temel ihtiyaç malzemelerini karşılamak için Türkiye ile ilişkileri geliştirmek zorunda kalmasıdır. Irak ile imzalanan yasal düzenlemeler çerçevesinde Ağustos 1986'da ve Mart 1987'de PKK'nın Irak sınırları içerisindeki kamp, depo ve sığınaklarını yok etmeye yönelik hava harekatları gerçekleştirilmiştir (http://www.aljazeera.com. tr/haber/tsknin-sinir-otesi-operasyonlari, 2011).

Diğer yandan, Türkiye'nin Irak ve Suriye nezdinde yürüttüğü girişimlerin uygulamadaki etkisi sınırlı ölçekte olmuş, PKK, önce Irak-İran savaşının bitmesiyle ortaya çıkan belirsizlikten ve daha sonra Körfez savaşı sonrası Irak'ta ortaya çıkan güç boşluğundan yararlanarak Irak'ın kuzeyinde daha güçlü bir aktör haline gelmiş ve eylem gücünü artırmıştır. Bunun üzerine Özal, Irak'ın kuzeyindeki gelişmeleri daha yakından takip etmek ve PKK’nın gücünü dengelemek için Kürdistan Yurtseverler Birliği (KYB) temsilcisi Celal Talabani ve Kürdistan Demokratik Partisi (KDP) başkanı Mesut Barzani ile işbirliğini güçlendirme yoluna gitmiştir (Cumhuriyet, 12 Mart 1991; Kayhan-Pusane, 2017: 46). Ancak, Özal'ın PKK'ya karşı KYB ve KDP’yi güçlendirme çabaları Irak yönetiminin Türkiye'nin etkisini azaltmak için PKK’nın Türkiye sınırına yerleşmesine dolaylı ya da doğrudan destek sağlaması nedeniyle etkili olmamıştır.

Irak'tan gelecek terör tehdidin önlenmesi konusunda sınır ötesi operasyon seçeneğine sahip olan Özal, Suriye'nin gerekli önlemleri almaması üzerine PKK'lı teröristlerin Suriye sınırından ya da sınırı geçerek yaptıkları saldırıların önlenmesi için Şam yönetimi ile işbirliğinin güçlendirilmesini hedeflemiştir. Özal'ın tutumu bir ülkeyi ilgilendiren sorunların çözülmesi için bu ülkeyle ilişkilerin tamamen sonlandırmaktan ziyade ilişkilerin daha da geliştirilmesi ve böylece beklentilerin daha iyi ifade edilmesi anlayışının bir uzantısıdır. Bir diğer husus, Özal'ın toplumsal yaşamda Irak ve Suriye'nin PKK'nın en büyük destekçisi olduğu ve hükümetin tehditleri önlemede yetersiz kaldığı şeklinde eleştirilerin yükseldiği ve seçime giden bir süreçte hem eleştirilerin önüne geçmek hem de seçim ortamında konumunu güçlendirmek istemesidir (Gökcan, 2019: 297). Güvenliği sağlamak ve politik alanda güç kazanmak için Özal, Temmuz 1987'de Suriye'ye bir ziyaret gerçekleştirmiş ve ziyaret sırasında imzalanan güvenlik protokolü ile taraflar topraklarında terörist eylemlere müsaade etmeyeceklerini belirtmişlerdir. Ayrıca, bu ziyaretin bir sonucu olan ekonomik işbirliği protokolü ile Türkiye, Suriye’ye 500 m3/sn'den fazla su bırakmayı taahhüt etmiştir. Taraflar oluşturdukları ekonomik düzenleme ile petrol-doğalgaz arama, elektrik enerjisi, bankacılık, ulaştırma ve haberleşme şeklinde sıralanabilecek alanlarda ekonomik işbirliğini geliştirmeyi 
hedeflemiştir (https://www.resmigazete.gov.tr/arsiv/19660.pdf, 1987). Suriye’ye yönelik işbirliği iradesinin bir diğer yansıması, 1988'de gündeme gelen Barış Suyu Projesi ile Ceyhan ve Seyhan nehirlerindeki ihtiyaç fazlası suların Ortadoğu ülkelerine taşınması ve kurulması planlanan ilk boru hattının Suriye'den geçeceğinin belirtilmesidir (Turan, 1993: 224-225). Özal, Suriye için öncelik taşıyan su meselesi konusunda olumlu bir tutum ortaya koyarak Türkiye ile Suriye arasında bir karşılıklı bağımlılık oluşmasını ve ortaya çıkacak karşılıklı bağımlılık ile Suriye'nin Türkiye’nin kaygılarını anlamasını, PKK'ya yönelik desteğini kesmesini ve uygulamada gerekli adımları atmasını hedeflemiştir (Ertosun, 2015: 204). Suriye’ye yönelik girişimler sonrası PKK kamplarının Suriye'den Bekaa Vadisine taşınması Özal'ın beklentisini bir ölçüde karşılayacak olsa da Şam yönetimi, Barış Suyu Projesi'ni Türkiye'nin bölgede etkinliğini artırmayı amaçlayan ve İsrail'in çıkarlarına hizmet eden bir proje olarak görmüştür (Erdoğan, 1998). Suriye’nin Barış Suyu Projesi'ne olumsuz yaklaşımı girişimin askıda kalmasına ve PKK'nın Suriye topraklarını kullanmaya devam etmesine neden olmuştur.

Suriye'nin PKK'ya yönelik desteğinin sürmesi nedeniyle, “Suriye PKK'ya yardım ederse sularını keseriz” şeklinde bir söylemle Özal, daha önce Suriye'yi ikna etmek için bir işbirliği unsuru olarak kullandığı su meselesini bu defa Suriye'yi PKK'ya yönelik desteğinden vazgeçirmek için politik bir araç haline getirmiştir (Ayman, 2012: 120). Dolayısıyla, Suriye'nin tutumu nedeniyle, Özal, yumuşak güç unsurları aracılığıyla Suriye'yi PKK konusunda işbirliğine yönlendirmeyi hedefleyen bir politikadan sert söyleme dayalı Suriye üzerinde baskı kurmayı amaçlayan bir politikaya geçiş yapmıştır. Körfez savaşı sürecinde Türkiye ve Suriye'nin Irak karşıtı pozisyonda yer almasının oluşturduğu olumlu konjonktürü iyi değerlendiren Özal bir kez daha diplomasi çerçevesinde Suriye'nin PKK'ya verdiği desteğin sonlanmasını hedeflemiş ve İçişleri Bakanı İsmet Sezgin ile Dışişleri Bakanı Hikmet Çetin Nisan 1992'de Suriye'yi ziyaret etmiştir. Ziyaret sırasında imzalanan güvenlik protokolü ile Şam yönetimi PKK'yı yasa dışı ilan ederek PKK’ya desteğini sonlandıracağını vaat etmiştir (Milliyet, 16 Nisan 1992; Milliyet, 19 Nisan 1992). Bununla birlikte, Özal'ın su meselesi aracılığıyla Şam'ın PKK'ya yönelik desteğini sonlandırma çabası ve güvenlik protokolü aracılığıyla Şam'ın desteğini kazanma hedefi uygulamada kayda değer bir etki ortaya çıkarmamış ve Şam yönetimi, PKK'ya yönelik desteğini devam ettirmiştir. Sonuç olarak, Özal'ın girişimlerinin Irak ve Suriye özelinde etkili olmaması ve PKK'nın eylemlerinin artarak devam etmesi Özal iktidarının son yıllarında ve Özal sonrası dönemde askeri seçeneklerin daha ön planda olmasına neden olmuştur. 


\section{İran}

Ticari liberalizmin, iki devletin birbirleriyle olan ilişkilerinde ekonomik ç1karlara önem vermesi halinde bunun siyasi ilişkilerde de olumlu sonuçlara yol açacağı argümanı (Howard, 2008), Özal döneminde İran özelinde Irak-İran savaşının bittiği tarih olan 1988'e kadar belli ölçüde uygulamaya aktarılmıştır. Fakat, 1988'de Irak-İran savaşının bitmesi ve Türkiye-İran ekonomik ilişkilerindeki düşüş ile iki tarafın ikincil planda tuttuğu sorun alanları gün yüzüne çıkmaya başlamıştır. Irak-İran savaşı sürecinde ve savaş sonrasında ilişkiler tarafların birbirlerine yönelik ideolojik temelli eleştirileri, ekonomik ilişkiler ve PKK konularında şu şekilde analiz edilebilir:

1979 İran İslam devrimi sonrası süreçte rejim ihracı politikası izleyen Tahran, Türkiye'yi karşıt ideolojinin etkisinden kurtarılması gereken bir aktör olarak görürken; 12 Eylül 1980 darbesi sonrası erken dönemde Kemalist temalara önem veren Ankara, İran'ı irticai hareketleri besleyen bir ülke olarak değerlendirmiştir. Bu durum her iki aktörün birbirlerinin toplumsal ve siyasi yaşamına yönelik ideoloji temelli eleştirilerde bulunmasına yol açmiştır (Çetinsaya, 1998). Ancak, 1983’te iktidara gelen Özal, Türkiye'nin mal ve sermaye girdisi elde etmesi noktasında İran'ın ciddi bir potansiyele sahip olduğunu düşünmekte ve İran'ı bölgesel konularla ilgili önemli bir muhatap olarak görmekteydi (Laçinok, 2007). Benzer şekilde, her ne kadar rejim ihracı politikası izlese de Tahran yönetimi, gerçekçi bir temelde, Irak savaşı nedeniyle ekonomik problemlerle karşılaştığı ve İslam devrimi sonrası süreçte ABD liderliğindeki Batı dünyasının İran karşıtı tutumu ön plana çıkardığı bir dönemde Türkiye ile ilişkilerin kötü bir nitelik kazanmaması gerektiğinin bilincindeydi (Sinkaya, 2014: 138). Dolayısıyla, uygulamada, Özal, ekonomik çıkarları önemsediği bir ortamda Tahran'ın ideolojik temelli eleştirilerini çok fazla dikkate almayan bir tutum içerisinde olmuş ve Batı dünyasının İran'ı uluslararası sistemden izole etme yönündeki çabalarına mesafeli yaklaşmıştır (Ataman, 2002: 137). Tahran yönetimi ise Irak savaşı nedeniyle ekonomik seçeneklerinin çok fazla olmadığı bir ortamda ekonomik alternatiflerini çeşitlendirme arayışında Türkiye ile ekonomik ilişkilere özel bir önem vermiştir. Tarafların birbirlerine yönelik bu tutumunun etkisiyle ideolojik eleştiriler 1988'e kadar olan süreçte iki aktör arasında pratikte ciddi bir sorun oluşturmamıştır.

Özal'ın ekonomik ilişkilere önem veren iradesi, Irak-İran savaşı sürecinde Türkiye'nin tarafsızlık pozisyonunu sürdürmesi ve Türkiye'nin Avrupa ile İran arasında bir geçiş noktasında bulunması Türkiye-İran ekonomik ilişkilerini kolaylaştıran unsurlar olmuştur (Sinkaya, 2014: 138). Taraflar ticareti, 
görece avantajlı olduğu ürün grubunu karşı tarafa satmak ve kendisinin ihtiyacı olduğu malı almak şeklinde sürdürmüşlerdir. Türkiye, İran'dan petrol alırken; karşılığında İran'a temel ihtiyaç mallarını satmıştır. Tarafların üstün olduğu alana dayalı ticaret felsefesi uygulamada etkisini olumlu bir şekilde göstermiş ve iki ülke arasındaki ticaret hacmi 1985 yılında 2 milyar dolara ulaşmıştır (Olson, 2005: 12). Özal'ın Türkiye ile Ortadoğu ülkeleri arasındaki ekonomik işbirliğinin ekonomik nitelikli örgütleri de içerecek şekilde genişlemesi düşüncesi İran'ın Türkiye ile ekonomik işbirliği yapma konusunda güçlü bir irade göstermesiyle gündeme gelmiştir. Bu iradenin bir yansıması olarak, 1985 yılında Türkiye, İran ve Pakistan, Ekonomik İşbirliği Teşkilatı'nı kurmuştur. Ekonomik İşbirliği Teşkilatı ile Türkiye ve İran aralarındaki ticari bağları geliştirerek bir serbest ticaret ağı oluşturmayı ve dünya ticaretinde daha etkin hale gelmeyi hedeflemişlerdir (Türkiye Cumhuriyeti Dışişleri Bakanlığı, Ekonomik İşbirliği Teşkilatı, t.y). Ekonomik İşbirliği Teşkilatı, iki ülke arasındaki ekonomik ilişkilerin daha güçlü temelde kurumsal bir nitelik kazandığının somut bir göstergesi olmuştur.

Özal, Türkiye'nin PKK ile mücadeleyi daha etkin bir şekilde yürütmesi için Ekim 1984'te Irak ile imzaladığı sıcak takip anlaşmasının benzerini İran ile imzalayarak Ortadoğu sınır güvenliğini sağlamayı hedeflemiştir. İran, Türkiye'nin sıcak takip talebine olumsuz yaklaşmış ancak Kasım 1984'te imzalanan anlaşma ile İran topraklarından Türkiye'nin güvenliğini tehdit eden faaliyetlere izin vermemeyi öncelik haline getiren bir tutum içerisinde olmuştur. İran'ın PKK konusunda Türkiye'nin kaygılarını dikkate alan bir tutum içerisinde olmasının temel nedeni Irak savaşının sürdüğü bir ortamda İran'ın ekonomik çıkarları açısından Türkiye’nin önemli bir pozisyonda olmasıdır. Başka bir deyişle, Tahran yönetimi, Türkiye'nin beklentilerine tamamen olumsuz bir şekilde yaklaşmanın süreci kendisi için daha olumsuz bir hale getireceğinin farkındaydı. Bu durum Tahran yönetiminin Irak savaşı boyunca PKK'nın İran topraklarını kullanmasının engellenmesine büyük bir özen göstermesine neden olacak ve Türkiye'ye yönelik İran kaynaklı PKK eylemlerinin sayısında azalma görülecektir (Çetinsaya, 1998: 152).

Özal'ın ekonomik ilişkilerin geliştirilmesinin politik sorunların yumuşamasında önemli rol oynayacağına ilişkin yaklaşımı İran özelinde somut bir şekilde görülmüş ancak 1988'te Irak-İran savaşının bitmesiyle birlikte ekonomik ilişkilerin Türkiye-İran ilişkilerine olumlu etkisinin devam etmesi mümkün olmamıştır. Bunun nedeni, savaşın bitmesiyle İran'ın Türkiye'ye olan ekonomik bağımlılığında kayda değer bir şekilde azalma olmasıdır. Nitekim, 1988 sonrası ekonomik ilişkilerde 1980'lerin ortalarında ulaşılan yüksek sayılarda kayda değer bir azalış yaşanmıştır (Robins, 1991: 103-104). Ayrıca, iki taraf 
arasında olan ancak ekonomik ilişkiler nedeniyle ikincil planda kalan sorunlar daha gözle görülür bir nitelik kazanmıştır. Örneğin, Mart 1989'da Anayasa Mahkemesi'nin üniversitelerde türban yasağı kararı üzerine Müslümanların haklarını her yerde savunma hakkı olduğuna inanan İran yönetimi, Türkiye’ye yönelik çeşitli eleştiriler ve suçlamalarda bulunmuş ve İran'ın Ankara büyükelçisi ekonomik yaptırımları gündeme getirmiştir (Robins, 1991: 56). Bir diğer husus, İran'ın Irak savaşı sırasında Türkiye'nin desteğini almak için arasına belli bir mesafe koyduğu PKK konusunda savaş sonrası dönemde savaş sırasında olduğu kadar kararlı bir tutum ortaya koymamasıdır. İran'ın PKK'ya yönelik kayda değer önlemler almaması PKK'nın İran topraklarını kullanmasına ve Ortadoğu'da hareket sahasını genişletmesine yol açmıştır. Dolayısıyla, tüm bu hususlar 1980-1988 arası dönemde iki tarafın belli ölçüde işbirliği halinde olduğu ekonomik ilişkiler ve PKK konularında işbirliği düzeyinin azalması ve tarafların birbirlerine yönelik dillendirdiği suçlamaların uygulamada sorunlara neden olması anlamına gelmiştir. Diğer yandan, İran'da Haşimi Rafsancani'nin yönetime gelmesiyle yeni yönetimin çıkar temelinde diş ilişkilere önem veren bir politika izlemesi (Elik, 2012) ve Eylül 1992'de PKK ile mücadele konusunda ortak bir güvenlik komitesi kurulması ilişkilerde belli bir yumuşaya yol açacak olsa da bu gelişmelerin etkisi sınırlı düzeyde olmuştur.

\section{Filistin Sorunu}

Liberalizmin bir devletin ulusal sistemdeki temel parametrelerinin uluslararası ilişkilere yönelik bakış açısını etkileyeceği fikri gibi (Kant, 1983; Paine, 1995), 1980'li yıllarda Türkiye'nin Ortadoğu politikasında Filistin sorununa yönelik yüksek bir ilgi göstermesinde ulusal sistemde yürütmenin başında bulunan Özal'ın Türkiye'nin Filistin sorununa özel bir önem vermesi gerektiğini düşünmesi oldukça etkili olmuştur (Özal, 1984: 984; Cumhuriyet, 16 Ocak 1984). Özal'ın hassasiyetinin iki nedeninin olduğu söylenebilir. İlk olarak, Özal, Türkiye'nin Ortadoğu ile olan kültürel bağlarının Filistin sorununu Türkiye için daha önemli ve anlamlı hale getirdiğine inanmaktaydı. İkinci olarak, Özal, Arap coğrafyasında barışı sağlamış bir devletin mirasçısı olarak kurulan Türkiye'nin Filistinlilerin barış içerisinde yaşamasında tarihsel bir sorumluluğu olduğu şeklinde bir düşünceye sahipti (Gürkaynak, 2007: 100). Bu noktalardan hareketle, Özal, Ekim 1985'te Tunus'ta Filistin Kurtuluş Örgütü (FKÖ) karargahına düzenlenen saldırı gibi İsrail'in Ortadoğu'da barışı daha zor hale getiren eylemlerine ve 1987'de başlayan birinci intifada sürecinde Filistinlilere yönelik ölçüsüz şiddet kullanımına söylem düzeyinde sert tepki göstermiştir. Ancak, Özal liderliğinde Türkiye, Ortadoğu devletleri için en önemli konulardan biri olan Filistin meselesinde İsrail'in eylemlerine 
yönelik eleştirel bir tutum geliştirmiş olsa da dönem itibarıyla kendisi için birincil öncelik taşıyan dış politika konularında Kıbrıs sorununda ve Bulgaristan'da Türklere yapılan insan hakları ihlallerinde bölge devletlerinin desteğini görememiştir (Sarıaslan, 2019: 16-17).

Liberalizmin anarşik uluslararası düzende işbirliğinin tesis edilebileceği ve işbirliğinin barışın ortaya çıkmasına katkı sağlayacağı argümanı gibi Özal da Filistin sorunu temelinde Arap devletleri ile İsrail arasında yaşanan ve süregelen kaotik durumun aslında kaçınılmaz bir son olmadığını ve İsrail'in varlığının inkâr edilmemesi ile Filistinlilerin haklarının tanınması çerçevesinde Ortadoğu'da barışın gündeme gelebileceğini iddia etmektedir. Özal, İsrail devletinin varlığını inkâr etmemekte ancak Filistinlilerin de Ortadoğu'daki diğer halklar gibi kendi siyasi oluşumlarını tesis etme hakkı olduğunu bunun da Filistinlilerin kendi aralarında güçlü bir birlik tesis etmesiyle ve uluslararası toplumun desteğiyle sağlanacağını belirtmektedir (Özal, 1984’ten aktaran Ertosun, 2015: 197). Filistinlilerin güçlü birlik tesis etmesi gibi iç ve uluslararası toplumun desteği gibi dış etkenlerin önemine değinen Özal, Türkiye'nin Filistin politikasında daha önceki dönemlerden farklı olarak iki yeni noktayı ortaya koymuştur: (i) Filistinlilerin bir siyasi oluşum tesis etme çabalarına destek olma (Milliyet, 28 Şubat 1986); (ii) uluslararası toplumun bir üyesi olarak Filistin-İsrail barış sürecinde işlevsel bir rol oynama ya da katkı sağlama (Özal, 1984: 285). Özal'ın ortaya koyduğu yaklaşımın bir yansıması olarak Türkiye, Filistin Ulusal Konseyi'nin 15 Kasım 1988'de kuruluşunu ilan ettiği Filistin devletini aynı gün tanımıştır (Milliyet, 16 Kasım 1988). Filistin devletini tanıma kararında daha önce İsrail'i tanıyan ilk Müslüman devlet olarak kendisi aleyhine olumsuz bir tutum geliştirilen Türkiye'nin benzer olumsuz algıların oluşmasını engelleme ve Arap devletlerinin sempatisini kazanma düşüncesinin etkili olduğu söylenebilir. Özal'ın politikalarının uygulamaya yönelik bir diğer yansıması, Filistin ile İsrail arasında barış görüşmelerinin gündeme geldiği bir konjonktürde Türkiye'nin üçüncü bir ülke olarak barış sürecinde arabulucu olmaya ya da sürece ev sahipliği yapmaya çalışmasıdır (Ataman, 2002: 136-137). Özal liderliğindeki Türkiye barış sürecinde aktif bir rol oynayamamasına rağmen sürecin ortaya çıkard1ğ1 pozitif atmosferin etkisiyle hem Filistin hem de İsrail ile olan diplomatik ilişkilerini büyükelçilik düzeyine yükseltecektir (Sayarı, 1997: 50).

\section{İsrail}

Liberal devletlerin uluslararası ilişkilerde birtakım eylemler ortaya koyarken rasyonel bir şekilde hareket edecekleri yaklaşımı (Gradner, 1990: 23-39; Starr, 
2007: 35), Özal'ın İsrail'e yönelik politikasında görüldü. Özal, İsrail ile ilişkilerin 'ilişkileri kesme' gibi aşırı bir uçta konumlandırmaktan ziyade rasyonel bir şekilde değerlendirilmesi gerektiğini düşünmekte ve diyalog kapısının her zaman için gündemde olmasının faydalı bir seçenek olacağına inanmaktadır (Laçinok, 2007). Özal, Filistin bağlamında İsrail'e yönelik eleştirel bir dil ortaya koymasına rağmen İsrail'e yönelik tümüyle karşıt bir tutum geliştirmek ya da İsrail'i Ortadoğu'daki bölgesel gelişmelerden soyutlamak gibi bir politika takip etmemiştir. Zira, Özal, İsrail ile ilişkilerin Türkiye için olumlu çıktılar sağlayacak şekilde gelişmesinin oldukça önemli olduğunu düşünmektedir (Laçinok, 2007).

Özal'ın İsrail'e yönelik politikanın ilk uzantısı, İsrail'in çeşitli projelere dahil edilmesi yoluyla İsrail ile Ortadoğu ülkeleri arasında olumlu bir atmosferin tesis edilmesiydi. Barış Suyu Projesi'nin Türkiye-İsrail-Suriye-Ürdün eksenindeki öngörülen ilk hattı bu anlayışı yansıtmaktadır. Özal, Barış Suyu Projesi gibi girişimlerle İsrail ve Arap ülkelerini su gibi ortak bir ihtiyaç temelinde bir araya getirmeyi, iki tarafın birbirini anlamasını ve böylece tarafların savaşı ikincil bir araç haline getirmelerini hedeflemiştir. Bununla birlikte, Arap devletlerinin projenin İsrail’i içermesi üzerine gösterdikleri sert tavır sürecin önünde önemli bir engel oluşturmuştur. İsrail'in proje dışına çıkarılması projenin temel mantığı olan Ortadoğu ülkelerini bir araya getirme ihtimalini ortadan kaldırmıştır (Ertosun, 2015: 205, 210). Dolayısıyla, Özal'ın yumuşak güç unsurları temelinde Ortadoğu'da bölgesel işbirliğinin gelişmesine katkı sağlayarak Türkiye'nin etkinliğini artırma misyonu tarafların birbirlerine yönelik düşmanca tutumu nedeniyle geçersiz hale gelmiştir.

Özal'ın politikasının ikinci yönü, ABD’deki Rum ve Ermeni lobilerinin kendi tezleri üzerinden Amerikan kongresinde Türkiye aleyhine oluşturdukları politik havanın engellenmesinde Yahudi lobisinin desteğini almak için İsrail'e yönelik olumlu bir tutumun ortaya konması olmuştur (Erhan, 2002: 251-259). 1980 sonrası Türkiye-ABD ilişkilerinin bir önceki döneme göre daha güçlü bir nitelik kazanması Türkiye ile İsrail arasındaki ilişkilerin yumuşamasında ve gelişmesinde etkili olmuştur. İsrail'e yönelik olumlu yaklaşım ve ABD'nin süreçteki etkisi Türkiye'nin belli ölçüde Yahudi lobisinin desteğini almasını sağlamıştır. Örneğin, 1989'da ABD kongresinde Ermeni soykırım tasarısının engellenmesinde Yahudi lobisinin desteği etkili olmuştur (Çelikkol, 2015: 22). Türkiye, 1989'da BM Genel Kurulunun açılışı sırasında, İsrail'in BM Genel Kurulunda temsil edilmesinin yasaklanması konusundaki tasarıya, daha önceki dönemlerde kullandığı çekimser oyun aksine, ret oyu vermiştir (Erhan, 2002: 251-259). Yahudi lobisinin Türkiye'ye yönelik desteği ve Türkiye'nin BM'de 
İsrail'e yönelik olumlu tutumu Türkiye-İsrail ilişkilerinin uluslararası boyutunun işbirliği çerçevesinde geliştiğini göstermekteydi.

\section{Körfez Ülkeleri}

Liberalizmin uluslararası ilişkilerde iki devlet arasındaki işbirliğinin ortak ç1kar olgusunun geçerli olduğu bir durumda ortaya çıkacağı argümanı (Haas, 1980: 357-406; 1987; Rosecrance, 1986), Özal döneminin büyük bir kısmında Türkiye ile Körfez ülkeleri arasındaki ilişkilerde geçerlilik kazanmıştır. Özellikle, Körfez savaşının başlamasına kadar olan süreçte Türkiye ile Körfez ülkeleri ekonomi, güvenlik ve bölgesel konular başlıklarında ortak çıkarları paylaşmışlar ve bu durum her iki aktörün Körfez Savaşı sırasında olduğu gibi bölgesel konulara ilişkin ortak bir perspektif benimsemesine yol açmıştır.

Ortak çıkarlar açısından değerlendirdiğimizde, Türkiye ve Körfez ülkeleri, Sovyetler Birliği’nin Afganistan'ı işgaliyle Soğuk Savaşın yeni bir görümüm kazandığı ve İran İslam devrimi ile İran'ın Ortadoğu siyasetinde din ekseninde daha ön plana çıktığı bir süreçte her iki gelişmenin kendilerine yönelik olumsuz etkilerinden endişelenmişlerdir. İran'ın devrim ihracı politikası çerçevesinde Türkiye ve Körfez ülkelerinin toplumsal yaşamını olumsuz yönde etkilemesinin engellenmesi ve Ortadoğu siyasetinde daha güçlü bir konuma gelmesinin önüne geçilmesi her iki devletin bölgesel konulara ilişkin ortak çıkarları olmuştur. Ayrıca, Sovyetlerin Afganistan üzerinden daha yayılmacı bir politika izleme olasılığı Türkiye ve Körfez ülkeleri için ortak bir güvenlik tehdit anlamına gelmiştir. Bu gelişmeler üzerine her iki aktör: (i) İran'ın devrim ihracı politikasına karşı 1lımlı İslam düşüncesini savunarak İran'ın din üzerinden Ortadoğu ülkelerinin ulusal sistemlerinde ve bölge genelinde güç kazanmasını engellemek istemişler; (ii) Afganistan'da yerel direnişçileri destekleyerek Sovyetler karşısında Afganlıların güçlenmesine katkı sağlamaya çalışmışlardır (Gözen, 2002). Türkiye ve Körfez ülkelerinin ortak bir perspektif geliştirmesinde ABD’nin Hizbullah gibi radikal akımları ve İran ile Sovyetler Birliği'nin etkisini sınırlandırmak amacıyla Ortadoğu'ya doğrudan bir müdahale yerine ‘llımlı İslam’ özelliğine sahip olduğunu düşündüğü bölge ülkelerini Yeşil Kuşak yaklaşımı çerçevesinde bir araya getirme stratejisi geliştirmesi yönlendirici bir dinamik olmuştur (Oran, 2001: 11). Uygulamada, İran'da 1989'daki lider değişikliğiyle daha ılımlı bir politika izleme taraftarı olan Haşimi Rafsancani'nin Cumhurbaşkanı olması ve Sovyetler Birliği'nin, birlik içerisindeki iç gelişmelerinde etkisiyle, Şubat 1989'da Afganistan'dan çekilmesiyle Türkiye ve Körfez ülkeleri dolaylı yoldan ortak çıkarlarını elde etmişlerdir. 
Ricardo'nun (1911) devletlerin üstün olduğu ticari malı diğer aktöre satmak ve kendisinin görece dezavantajlı durumda olduğu ticari malı diğer aktörden satın almak şeklindeki 'karşılaştırmalı üstünlükler' olarak kavramsallaştırdığı ticaret anlayışı Türkiye ile Körfez ülkeleri arasındaki ilişkilerde geçerlilik kazanmıştır:

Özal liderliğindeki Türkiye, Körfez ülkeleri ile ekonomik ilişkiler geliştirerek Körfez ülkelerinin üstün olduğu bankacılık ve finans alanından olumlu çlktılar elde etmeyi hedeflemiştir (Özev, 2016). 24 Ocak kararları ile dış ekonomik ilişkilerin gelişmesinin önündeki engelleri kaldıran Özal, iktidara gelmesinin ardından Türkiye'nin uluslararası ekonomiyle bütünleşmesinin güçlü savunucusu olmaya devam etmiştir. Özal, içeriğinin belirlenmesinde önemli bir rol oynadığı özel finans kuruluşların faaliyetlerine ilişkin kararların Başbakanlıkça alınmasını öngören kararname ve Suudi merkezli Faysal Finans kurumunun Türkiye'de faaliyet göstermesine izin verilmesi kararı gibi yasal düzenlemelerle Körfez sermayesinin Türkiye'de yatırımlar yapmasının zeminini oluşturmuştur. Bu düzenlemelerin ortaya çıkmasında Özal'ın Türkiye'nin olumlu ekonomik girdiler elde etmesinde Suudi Arabistan gibi Körfez ülkeleri ile geliştirilen ilişkilerin önemli bir rol oynayacağını düşünmesi etkili olmuştur (Fırat ve Kürkçüoğlu, 2001). Gerekli yasal düzenlemelerin sağlanmasiyla uygulamada Suudi Arabistan, Türkiye’ye 1987’ye kadar 750 milyon dolara varan bir destek sağlamış, Suudi Kalkınma Fonu çeşitli krediler vermiş ve Türkiye'de faaliyet gösteren Suudi girişimlerinin sayısında artış olmuştur (Özev, 2016: 19). Suudi merkezli finansman kaynakları Türkiye ekonomisinin büyümesinde olumlu bir unsur olarak yer almış ve Türkiye'nin dışa açllma sürecinde kayda değer ölçüde bir yabancı sermaye elde etmesini sağlamıştır.

Diğer yandan, 1980'lerde Körfez ülkeleri, İran devriminin ve Irak-İran savaşının kendilerine yönelik olumsuz yansımaları olabileceği gerekçesiyle ordularının modernizasyonuna oldukça önem vermişlerdir (Fırat ve Kürkçüoğlu, 2001). Bölgesel gelişmelerden olumsuz yönde etkilenme kaygısı Körfez ülkelerinin bölgede güçlü bir orduya sahip olan Türkiye ile ilişkileri geliştirmeyi öncelik haline getirmesinde etkili olmuştur. Örneğin, Körfez ülkelerinden Suudi Arabistan, ortak askeri tatbikat çerçevesinde Türkiye'nin tecrübelerinden faydalanmak istemiş ve savaş uçağı gibi bazı stratejik ürünlerin üretimi konusunda Türkiye ile anlaşmalar imzalamıştır (Özev, 2016: 19). Belli ölçüde işbirliğini içeren ikili düzenlemelerle Suudi Arabistan gibi Körfez ülkeleri askeri kapasitelerinin güçlenmesi konusunda önemli ilerleme sağlamışlardır. Ayrıca, Körfez ülkeleri, Türkiye ile geliştirilen güçlü ilişkiler yoluyla Ortadoğu bölgesel sisteminde devrim ihracı politikası takip eden İran'ı bölgede dengeleyebilecek bir aktörün desteğini kazanmışlardır. 
Türkiye ve Körfez ülkeleri arasındaki işbirliği Irak'ın Kuveyt'i işgali ve akabinde ABD liderliğindeki koalisyon güçlerinin Irak’a müdahalesiyle yaşanan Körfez savaşı sürecinde devam etti. Ancak, Körfez savaşı sonrası yaşanan gelişmeler Türkiye ile Körfez ülkeleri arasındaki ilişkilerin işbirliğinden uzaklaştığını göstermekteydi. Savaş sırasında Suudi Arabistan, Kuveyt ve Birleşik Arap Emirlikleri; Türkiye'den silah alacaklarını ifade etmelerine rağmen savaş sonrası dönemde bu yönde bir irade göstermediler ve Türkiye'nin zararlar1nı karşılamak amacıyla 3 milyar dolarlık yardım yapacaklarını belirtmelerine rağmen bu yardımı ödemekte son derece yavaş davrandılar (Fırat ve Kürkçüoğlu, 2001: 553). Bu noktadan hareketle, Körfez ülkelerinin Körfez savaşı sonrası dönemde Türkiye ile ilişkileri geliştirme konusunda savaş öncesi kadar istekli olmadıkları söylenebilir. Bu durum liberal uluslararası ilişkiler perspektifinin belirttiği ortak çıkarlar tesis edilmediği takdirde devletler arasındaki ilişkilerin işbirliği niteliği kazanamayacağı ve bir devletin diğer devletin eylemlerini kendi çıkarlarına zarar verecek bir gelişme olarak değerlendirmesinin işbirliği sürecinin önünde bir engel olacağı görüşüyle yakından ilgilidir. Nitekim, Körfez savaşı sonrası erken dönemde, Körfez ülkeleri, bölgesel gelişmelerle ilgili konularda Türkiye'nin sürece dahil olmasının kendi çıkarlarına zarar verecek bir gelişme olarak gördü. Körfez ülkeleri, İran'ın Ortadoğu'daki etkinliğinin önlenmesi ya da dengelenmesi noktasında ABD'nin daha işlevsel bir rol oynayacağını düşünmüşler (Kılınç, 2000: 16-19) ve bu görüşün etkisiyle Türkiye'nin ABD öncülüğünde oluşacak yeni bölgesel güvenlik sisteminde veyahut bölgesel politikada etkin bir aktör olarak görmek istememişlerdir (Fırat ve Kürkçüoğlu, 2001: 553). ABD’nin Körfez savaşı ile Ortadoğu gelişmelerine doğrudan müdahil olmaya başladığı bir süreçte Körfez ülkelerinin güvenliklerini sağlama ve askeri kapasitelerini güçlendirme konusunda Batı ile ilişkilere öncelik vermeleri (Ekşi, 2009: 121), Türkiye ile ilişkilerin düzeyinde bir düşüşe yol açmıştır.

\section{Körfez Savaşı}

2 Ağustos 1990'da Irak'ın Kuveyt'i işgal etmesinin ardından ABD liderliğindeki koalisyon güçlerinin Irak’a yönelik müdahalesiyle başlayan Körfez savaşı (Ağustos 1990-Şubat 1991) sürecinde Özal Türkiye'nin politikasını ABD’nin eylemlerini desteklemek olarak şekillendirdi. Liberal uluslararası ilişkiler teorisi açısından Özal'ın politik tercihi, uygulamadaki eylemleri ve elde ettiği sonuçlar şu şekilde analiz edilebilir:

Liberal devletlerin uluslararası ilişkilerde ortaya koyduğu eylemlerde sonuç odaklı hareket ederek olumlu sonuçlar elde etmeyi öncelik haline 
getireceği ve piyasa ekonomisini güçlendirmek ile barış ve güvenliği sağlamak hedefleri çerçevesinde hareket edeceği görüşü (Starr, 2007: 35), Özal'ın Körfez savaşına yönelik politikasında görülmüştür. Özal, Körfez savaşı sonrası süreçte Irak'ın parçalanacağını ya da yeniden yapılanacağını dolayısıyla her iki durumda da Ortadoğu siyasetinde yeni bir dönemin başlayacağ1nı düşünmekteydi (Çandar, 2013: 32). Dolayısıyla, Özal'ın Türkiye’nin Körfez savaşı sırasında aktif bir politika izlemesiyle ve ABD'nin politikalarını desteklemesiyle hem savaştan hem de savaş sonrası süreçten olumlu sonuçlar elde edeceğini düşündüğü söylenebilir. Özal’a atfedilen "bir koyup üç almak” şeklindeki söylemlerle Türkiye’nin bu süreçte Musul ve Kerkük üzerinde bir etkinlik tesis etmeye çalıştığı şeklindeki yorumlar gündeme gelmiştir. Bununla birlikte, Irak’a ait topraklar üzerinde egemenlik tesis etmeye çalışmaktan ziyade Özal'ın temel amacının Körfez savaşı sonrası süreçte ekonomik kazançlar elde etmek ve Türkiye'nin güvenliğine yönelik bir tehdit oluşturan ve Irak'ın kuzeyinde yaşama alanı bulan PKK terör örgütünün daha güçlü hale gelmesini engellemek olduğu ifade edilebilir (Gözen, 2000).

Liberal devletlerin uluslararası ilişkilerde geliştirdikleri eylemlerle liberal demokratik ülkeler arasında ilişkileri güçlendirmeyi isteyecekleri çalışmada daha önce ifade edilmişti (Starr, 2007: 35). Özal, Körfez savaşı sırasında ABD'nin politikalarını desteklemekle Türkiye'nin liberal Batı dünyası için stratejik önemi devam eden bir ülke olduğunu göstermeyi ve daha önemlisi liberal Batılı ülkelerle ilişkilerini güçlendirmeyi hedeflemiştir. Özal, Irak'ın Kuveyt'i işgalini ve akabinde Körfez savaşını uluslararası alanda Soğuk Savaşın bittiği ve uluslararası sistemin Batı ile Doğu bloku şeklinde iki kutuplu yapısının sona erdiği bir dönemde devletlerin uluslararası ilişkilerde pozisyonlarını yeniden tanımlayacakları bir olay olarak algılamıştır (Gözen, 2000). Özal, Türkiye'nin Soğuk Savaş döneminde olduğu gibi ABD için bölgede stratejik önemi olan ve bu niteliği devam eden bir ülke olduğunu göstererek Türkiye'nin uluslararası ilişkilerde liberal Batı dünyası ile bağlantısını korumayı hedeflemiştir. Daha önemlisi, Türkiye'nin Körfez savaşında ABD’nin yanında yer almasıyla Batı dünyasını ilgilendiren $A B$ üyeliği, Kıbrıs'ta konumunu güçlendirme ve askeri yardım gibi dış politika meselelerinde ABD’nin desteğini almayı arzu etmiştir (Abramowitz, 2013: 41-42). Diğer bir deyişle, Özal, Türkiye'nin Körfez savaşı sırasında ABD'nin politikalarını desteklemesi halinde, savaş sonrası dönemde yeni dünya düzeninin lideri olan ABD’nin Türkiye'nin karşı karşıya olduğu çeşitli dış politika sorunlarında Türkiye'ye yardımcı olacağını varsaymıştır.

Liberalizmde, David Hume'un (1963: 346-37) belirttiği cumhuriyetçi ya da demokratik sistemle yönetilen devletlerin belirlediği hedeflere ulaşmak 
için diğer devletlere yönelik askeri müdahaleyi, politik baskıyı ve muhaliflerin finanse edilmesi şeklindeki yöntemlere başvurabileceğini ifade eden 'düşüncesizce sertlik' durumu Özal'ın Körfez savaşı sırasındaki eylemlerinde görülmüştür. Örneğin, Özal'ın Kerkük-Yumurtalık petrol boru hattını hızlıca kapatması ve kapatma işlemini ABD başkanı George H. W. Bush'un talepte bulunmasını beklemeden yapması bu durumun bir göstergesidir. Özal'ın bu davranışı nedeniyle 1989-1991 arasında ABD’nin Türkiye büyükelçiliğini yapan Morton Abramowitz (2013: 34-46) Özal için “... Saddam’ın ayrılışını hızlandırmak için erken bir savunucuydu..." ifadesini kullanacaktır (Vurgular bana aittir). Uluslararası alanda Birleşmiş Milletler Güvenlik Konseyi’nin ambargo kararı alması Özal'ın petrol boru hattını kapatması eylemine meşruluk kazandırırken aynı zamanda eyleminin çok taraflı bir platformun kararına uygun olduğunu göstermesine olanak sağlamıştır.

Özal'ın süreçteki diğer bir eylemi, ikili anlaşmalar ve NATO çerçevesinde Türkiye'deki askeri üslerin ABD tarafından kullanılmasına müsaade etmesi ve Irak sınırına asker konuşlandırarak Irak'ın askeri kuvvetlerinin bir kısmını kuzeye kaydırmasına dolayısıyla güneydeki askeri varlığının azalmasına katkı sağlamasıdır. Özal'ın sertlik yanlısı bir tutumda olduğunun bir diğer göstergesi Türk Silahlı Kuvvetleri'ni kullanarak Türkiye'nin fiili olarak sahada yer almasını istemesi olmuştur. Dönem boyunca dış politika ile ilgili konularda dışişleri bürokrasisinin etkinliğini sınırlayan Özal bu eylemini sivil ve askeri kesimin güçlü bir tepkisiyle karşılaşınca uygulamaya aktaramamıştır (Milliyet, 13 Ekim 1990; Milliyet, 4 Aralık 1990; Milliyet, 23 Mayıs 1995). Liberalizmin devletin bireylerden, bürokrasiden ve dış politikayı etkilemeye çalışan çeşitli çıkar gruplarından oluşacağı ve dış politika kararlarının bu aktörler arasındaki uzlaşıdan ya da süreçte baskın olan bir aktör tarafından alınacağı görüşü çerçevesinden incelendiğinde (Moravcsik, 2001: 5-9; Kaarbo, 2015: 8-9), Özal'ın karşısında sivil ve askeri bürokrasinin yer alması bir uzlaşının sağlanamamasına ve Özal'ın istediği yönde adım atamamasına neden olmuştur. Özal, askeri unsurları sahada kullanamamasına rağmen Türkiye, Körfez savaşı sırasında ABD liderliğindeki koalisyonu en güçlü şekilde destekleyen ülkelerin başında gelmiştir. Bununla birlikte, Özal'ın güçlü desteğine rağmen Türkiye'nin Körfez savaşı sonrası süreçte istediği sonuçları elde edemediği söylenebilir:

Her şeyden önce belirtilmesi gereken husus, Özal'ın Ortadoğu'ya yönelik politikalar aracılığıyla Batı dünyasına Türkiye'nin stratejik öneminin devam ettiğini gösterme ve Batılı liberal ülkelerle ilişkileri geliştirme hedeflerinde sınırlı olumlu sonuçlar elde edilmiştir. Savaş sırasında ve savaş sonrası dönemde Türk-Amerikan ilişkileri daha da güçlenmiş ve Washington diş 
politikayla ilgili bazı konularda Türkiye’yi desteklemiş olsa da bu destek sınırlı ölçekte olmuştur. Fakat, uzun vadede, Batılı liberal devletler, Türkiye’yi PKK'ya yönelik mücadelede Doğu ve Güneydoğu Anadolu'da insan hakları ihlallerinde bulunduğu gerekçesiyle eleştirmişlerdir (Uslu, 2016).

Ticari liberalizmin etkisinin görüldüğü Türkiye'nin Ortadoğu devletleri ile olan ekonomik ilişkileri Körfez savaşı nedeniyle ciddi zararlar görmüştür. Özal'ın Türkiye'yi Irak'ın karşısında konumlandırmasıyla Irak ile siyasi ve ekonomik ilişkiler en alt düzeye inmiş ve savaş sırasında Kerkük-Yumurtalık petrol boru hattının kapatılması nedeniyle Türkiye savaş sonrasında da etkisi hissedilecek şekilde kayda değer ekonomik zarara uğramıştır (Hürriyet, 25 Kasım 1992). 1995 yılı itibarıyla Türkiye'nin Körfez savaşı nedeniyle uğradığı ekonomik kaybın 20 milyar dolar olduğu tahmin edilmektedir (Gözen, 2000). Ayrıca, Körfez ülkelerinin savaş sırasında Türkiye'den silah alacakları şeklindeki beyanatları savaş sonrasında gerekli adımları atmamaları nedeniyle geçerlilik kazanmamış dolayısıyla Türkiye ekonomik açıdan beklediğini bulamamıştır. Ekonomik kayıpların yanı sıra, Özal'ın Körfez savaşı sürecinde aktif bir politika izleyerek PKK terör örgütünün daha tehlikeli bir hale gelmesini engelleme hedefinde başarısız olduğu söylenebilir. Irak hükümeti, Körfez savaşı sırasında Türkiye'nin kendisine karşı bir tutum geliştirmesi nedeniyle PKK'yı engellemeye yönelik güçlü adımlar atmamıştır. Dolayısıyla, Körfez savaşı sırasındaki güç boşluğundan yararlanarak Irak'ın kuzeyinde güçlenen PKK, 1990’lı yıllar boyunca, Türkiye'nin güvenliğine yönelik önemli bir tehdit oluşturmuştur.

Körfez savaşı sürecinde yaşanan bir diğer önemli gelişme ABD’nin savaş sırasında Irak'ı zayıflatmak için Kürt isyanını tetiklemesi sonucu Kürtlerin ayaklanması ve Irak'ın ayaklanmayı bastırması sonucunda Kürtlerin Türkiye sınırına yönelmesi nedeniyle mülteci sorununun ortaya çıkması olmuştur. Liberalizmin uluslararası hukuk normlarının uygulanmasının, insan haklarının tesisinin ve insani güvenliğin sağlanmasının barış ve istikrarın sağlanmasında son derece önemli görmesi gibi (Rawls, 1999), Özal'da Türkiye'nin sınır güvenliğinin sağlanması için mülteci sorununun önüne geçilmesini ve bu nedenle Irak'ın kuzeyindeki Kürtlerin insan güvenliğinin sağlanmasını hedeflemiştir. Özal, mülteci sorununu çözmek amacıyla Batılı liberal devletlerden güvenli bölge talebinde bulunmuş ve bu devletlerin desteğiyle çok taraflı bir işbirliği girişimiyle sorunun önüne geçilmesini arzu etmiştir. Uygulamada, kısaca Çekiç Güç olarak adlandırılan Huzur Ortak Görev Gücü’nün İncirlik üssünden hareket ederek Irak'ın kuzeyindeki Kürtlere yardımlar yapması Özal'ın talebinin uygulamada karşılık bulduğunu göstermekteydi (Hürriyet, 3 Nisan 1991; Cumhuriyet, 5 Nisan 1991; Hürriyet, 24 Kasım 1992). Bununla birlikte, Özal'ın mülteci sorununun çözülmesinde ve Türkiye'nin sınır güvenliğinin 
sağlanmasında önemli bir rol oynayacağını düşündüğü Çekiç Güç, 1990’lı yıllar boyunca PKK’ya yardım ederek Türkiye'nin güvenliğine zarar verdiği şeklindeki iddiaların odak noktasında yer alacaktır (Özkan, 2004; Dündar, 2016: 14). Ayrıca, Irak'ın kuzeyi KDP, KYB ve PKK gibi aktörler arasında çeşitli güç mücadelelerinin yaşandığı bir yer haline gelmiş ve Türkiye, Irak'ın kuzeyinde aktörler arasında yaşanan mücadelelerin çoğundan Türkiye'ye yönelik terör saldırılarının artması gibi olumsuz bir şekilde etkilenmiştir.

\section{Sonuç}

$\mathrm{Bu}$ çalışma liberal uluslararası ilişkiler teorisinin devletlerin uluslararası ilişkilere yönelik bakış açısının şekillenmesinde ulusal dinamiklerin belirleyici olacağı savının Turgut Özal döneminde Türkiye'nin Ortadoğu'ya yönelik yaklaşımında geçerli olduğunu göstermiştir. Ulusal düzlemde Özal gibi Ortadoğu ile ilişkilere önem verilmesi gerektiğini düşünen bir liderin yürütmenin başında olması Türkiye'nin bölgeye yönelik yaklaşımını şekillendirmiştir. Özal, 24 Ocak kararları çerçevesinde ihracata dayalı ekonomik büyümeye önem vermiş, kültürel bir kimlik olarak İslam bağlamında Türkiye'nin Ortadoğu bağlantısının Batıcı kimlikle bir çelişki olmadığını savunmuş ve Türkler ile Arapların ortak bir tarihsel geçmişe ve benzer kültürel değerlere sahip olduğunu belirtmiştir. Özal, Ortadoğu'ya yönelik politikada ekonomik ilişkilerin kapsamlı bir şekilde gelişmesini ve ekonomik ilişkilerin gelişmesi yoluyla ikili sorunların çözülmesi veyahut ciddi bir gündem maddesi oluşturmamasını hedeflemiştir. Özal, dış politika araçları olarak diplomasiyi, ekonomik anlaşmaları ve projeleri ön plana çıkarmış, Türkiye'yi statükocu bir pozisyona ittiğini düşündüğü dışişleri bürokrasisini sınırlayarak çoğu girişimi bizzat kendisi yürütmüş ve Körfez savaşı sürecinde görüldüğü gibi en radikal kararları tek başına almaktan kaçınmamıştır.

Çalışma Keohane'nin belirttiği liberal uluslararası ilişkiler perspektifinin cumhuriyetçi liberalizm, ticari liberalizm, düzenleyici liberalizm ve sosyolojik liberalizm şeklindeki dört alt dalından ticari liberalizmin Özal döneminde Türkiye'nin Ortadoğu politikasının içeriğini oluşturan temel unsur olduğu sonucuna ulaşmıştır. Ticari liberalizmin devletler arası ilişkilerde ortak çıkarların söz konusu olması halinde işbirliğine dayalı bir politik ortamın hâkim olacağı argümanı dönemin büyük kısmında Türkiye ile Ortadoğu ülkeleri arasındaki ilişkilerde görülmüştür. Özal liderliğindeki Türkiye'nin Ortadoğu'ya yönelik politikada elde ettiği olumlu çıktılar, Türkiye ile Ortadoğu ülkeleri arasında ortak/karşılıklı çıkarların söz konusu olduğu durumlarda ortaya çıkmıştır. Türkiye'nin Irak ile imzalanan anlaşma çerçevesinde PKK'ya karşı sıcak takip hakkı elde etmesi ve İran ile ilişkilerden önemli ekonomik 
kazançlar sağlaması Irak-İran savaşının sürdüğü bir ortamda Irak ve İran'ın Türkiye ile ilişkileri geliştirmek istemesinden kaynaklanmıştır. Benzer şekilde, Özal'ın Körfez ülkelerine yönelik açılımının başarılı olmasında ve bu ülkelerden Türkiye’ye yönelik sermaye girişinde Körfez ülkelerinin ulusal güvenlik sistemlerini güçlendirmede Türkiye'nin tecrübelerinden faydalanmak istemeleri etkili olmuştur. 1980'lerin ikinci yarısından itibaren İsrail ile ilişkilerin gelişmesi ve Yahudi lobisinin uluslararası alanda Türkiye'ye destek sağlaması birbiriyle bağlantılı gelişmelerdir. Belli düzeyde ortak/karşılıklı çıkarlar tesis edildiği ölçüde İran ile ideolojik gerginliklerin belli bir süreliğine ikinci plana itilmesi, İran'ın PKK eylemlerini engellemeye yönelik bir tutum içerisinde olması ve Körfez ülkeleri ile bölgesel konulara ilişkin benzer bir tutum geliştirilmesi söz konusu olmuştur.

Liberal uluslararası ilişkiler teorisinin belirttiği eğer bir aktörün ortaya koyduğu işbirliği perspektifi diğer aktörler tarafından kendi egemenliklerine ve çıkarlarına zarar verecek bir süreç olarak algılanıyorsa, bunun işbirliğinin önünde bir engel olacağı şeklindeki durum Türkiye'nin Irak ve Suriye ile ilişkilerinde geçerlilik kazanmıştır. Özal'ın ekonomi alanında geliştirilen ilişkiler ile projelerin ikili sorunların çözülmesine ve bölgesel barışın gerçekleşmesine katkı sağlayacağı şeklindeki argümanı Türkiye'nin PKK ve su sorunu nedeniyle sorunlar yaşadığı Irak ve Suriye ile ilişkilerde uygulamaya aktarılamamıştır. Irak ve Suriye, Türkiye’nin işbirliği iradesini ve ortaya koyduğu girişimleri Türkiye'nin bölgede etkinliğini artırmaya yönelik bir çaba olarak değerlendirmişler ve uzlaşmaz tutumunu sürdürmüşlerdir.

Diğer yandan, çalışma, Özal iktidarının son yıllarında Türkiye ile Ortadoğu ülkeleri arasındaki ilişkilerin niteliğinde bir değişim yaşandığını göstermiştir. Irak-İran savaşının bitmesi neticesinde Irak ve İran'ın Türkiye’ye olan ekonomik bağımlılıklarında azalma olması ve Körfez savaşı sonrası süreçte ABD'nin Ortadoğu'da etkin olarak yer almaya başlamasıyla birlikte Körfez ülkelerinin çıkarlarını gerçekleştirme noktasında Türkiye'nin desteğine ihtiyaçları kalmamaları Türkiye ile Ortadoğu ülkeleri arasındaki işbirliğinin düzeyinde bir azalmayı beraberinde getirmiştir. Suriye'nin PKK konusunda gerekli adımları atmaması ve Körfez savaşı sonrası PKK’nın daha güçlü hale gelmesi, Özal'ın Ortadoğu'ya yönelik politikalarda barış, istikrar ve güvenliğin sağlanmasını daha öncelikli hale getirmesine ve bu çerçevede hem suyu politik bir araç olarak kullanmasına hem de askeri araçları tercih etmesine yol açmıştır. Bu noktalardan hareketle, Körfez savaşı sonrası dönemde Türkiye ile Ortadoğu ülkeleri arasında ortak/karşılıklı çıkarların tesis edilememesinin Türkiye ile Ortadoğu ülkeleri arasındaki sorunların daha görünür hale gelmesine yol açtığı söylenebilir. 


\section{Kaynakça}

Abramowitz, M. (2013). Remembering Turgut Ozal: Some Personal Recollections. Insight Turkey, 15(2), 37-46.

Aljazeera.com.tr (2011), http://www.aljazeera.com.tr/haber/tsknin-sinir-otesi-operasyonlari.

Altunışık, M. B. (2009). Worldviews and Turkish foreign policy in the Middle East. New Perspectives on Turkey. 40, 171-194.

Aral, B. (2001). Dispensing with Tradition? Turkish Politics and International Society during the Özal Decade, 1983-93. Middle Eastern Studies, 37(1), 72-88.

Ataman, M. (2002). Leadership Change: Özal Leadership and Restructuring in Turkish Foreign Policy. Alternatives, 1(1), 120-153.

-------. (2003). Özalist Dış Politika: Aktif ve Rasyonel Bir Anlayış. Bilgi, 7(2), 49-64.

Ayman, S. G. (2012). İyi Komşuluğun Formülü: Türk Dış Politikasında Teritoryal Sorunlar. İstanbul: Yalın Yayıncilık.

Bentham, J. (2009). [1789]. An Introduction to the Principles of Morals and Legislation. Indianapolis: Dover Publications.

Burchill, S. (2005). Liberalism. Scott Burchill, Andrew Linklater, Richard Devetak, Jack Donelly, Matthew Paterson, Christian Reus-Smit and Jacqui True. Theories of International Relations içinde (s. 55-83). Third Edition, New York: Palgrave MacMillan.

Çakmak, H. (2013). Turgut Özal'ın Dış Politika Felsefesi ve Uygulamaları. Haydar Çakmak (Ed.). Liderlerin Dış Politika Felsefesi ve Uygulamaları içinde (s. 117-123). İstanbul: Doğu Kitabevi.

Çandar, C. (2013). Turgut Özal Twenty Years After: The Man and the Politician. Insight Turkey, 15(2), 27-36.

Çelikkol, A. O. (2015). Ermeni “Soykırım” İddiaları, Amerikan Kongresi ve Türkiye. Bilge Strateji, 7(13), 17-30.

Cumhuriyet. (1984, 16 Ocak). Özal: Ortadoğu'da Rol Oynamaktan Kaçınmayız.

Cumhuriyet (1991, 12 Mart).

Cumhuriyet (1991, 5 Nisan).

Çetinsaya, G. (1998). Türk-İran İlişkileri. Faruk Sönmezoğlu (Der.). Türk Dış Politikasının Analizi içinde (s. 135-158). İkinci Basım, İstanbul: Der Yayınları.

Duman, M. Z. (2011). Turgut Özal'ın Politikalarında Ekonomik Rasyonalizm. Sosyoloji Dergisi, 23-24, 105-123.

Dündar, L. (2016). Özal Dönemi Türk Dış Politikasında Turgut Özal'ın Kişisel Özelliklerinin Rolü. Ankara Üniversitesi Türk Inkılâp Tarihi Enstitüsü Atatürk Yolu Dergisi, 58, 1-20.

Ekşi, M. (2009). Körfez'de Güvenlik: Güvenlik Sistemi, Güvenlik Sorunları ve Yapılanmaları. Akademik Ortadoğu, 3(2), 113-130.

Elik, S. (2012). Iran-Turkey Relations, 1979-2011: Conceptualising the Dynamics of Politics, Religion and Security in Middle-Power States. New York: Routledge.

Erdoğan, İ. (1998). Su Sorunu, Ortadoğu ve Türkiye: Bölgesel Bir Analiz. İhsan D. Dağı (Der.). Türk Dış Politikasında Gelenek ve Değişim içinde (s. 143-179). Ankara: Siyasal Kitabevi.

Erhan, Ç. (2002). Türkiye'nin İsrail ile Iliş̧kileri (1948-2001). Türkler, 17, 251-259. 
Ertosun, E. (2015). Özal'ın Orta Doğu Barışı Perspektifi. Erkan Ertosun ve Erkan Demirbaş (Ed.). Turgut Özal: Değişim, Dönüşüm içinde (s. 191-217). Ankara: Turgut Özal Üniversitesi Yayınları.

Fırat, M. ve Kürkçüoğlu, Ö. (2001). 1980-1990 Dönemi: Arap Devletleriyle Iliş̧kiler. Baskın Oran (Ed.). Türk Dış Politikası: Kurtuluş Savaşından Bugüne Olgular, Belgeler, Yorumlar, Cilt:2, 1980-2001 içinde (s. 124-148). İstanbul: Illetişim Yayınları.

Gilpin, R. (1987). The Political Economy of International Relations. Princeton: Princeton University Press.

Gökcan, Ö. (2019). Türkiye’nin Suriye Politikasında Turgut Özal Dönemi. Anemon Muş Alparslan Üniversitesi Sosyal Bilimler Dergisi, 7(4), 293-305.

Gözen, R. (2000). Amerikan Kıskacında Dış Politika: Körfez Savaşı, Turgut Özal ve Sonrası. Ankara: Liberte Yayınları.

--------. (2002). Türkiye’nin Ortadoğu Politikası Gelişimi ve Etkenleri. Türkler, 17, 233-268.

Gradner, R. N. (1990). The Comeback of Liberal Internationalism. The Washington Quarterly, 13(3), 23-39.

Gürbey, G. (2001). Özal'ın Dış Politika Anlayışı. İhsan Sezal ve İhsan Dağı (Ed.). Kim bu? Özal, Siyaset, Iktisat, Zihniyet içinde (s. 287-305). İstanbul: Boyut Kitapları.

Gürkaynak, E. Ç. (2007). Turkey as a Third Party in Israeli-Palestinian Conflict: Assesment and Reflections. Perceptions, 12(1), 89-108.

Haas, E. B. (1980). Why Collaborate? Issue Linkage and International Regimes. International Organization, 32(3), 357-406.

------. (1997). Nationalism, Liberalism, and Progress: The Rise and Decline of Nationalism. New York: Cornell University Press.

Hobbes, T. (1998). [1651]. Leviathan. Oxford: Oxford University Press.

Howard, M. (2008). War and the Liberal Conscience. London: Hurst Publishers.

Hume, D. (1963). [1741-1742]. Essays: Moral, Political and Literary. London: Oxford University Press.

Hürriyet. (1988, 1 Mart). Özal ve Dış Politika.

Hürriyet (1991, 3 Nisan).

Hürriyet (1992, 24 Kasım).

Hürriyet (1992, 25 Kasım).

Jackson, R. Sorensen G. Moller J. (2018). Introduction to International Relations: Theories and Approaches. Seventh Edition, Oxford: Oxford University Press.

Kant, I. (1983). [1795]. Perpetual Peace and Other Essays on Politics, History, and Moral Practice. Indianapolis: Hackett Publishing.

--------. (1991). Political Writings. H. S. Reiss (Ed.), Cambridge: Cambridge University Press.

Kaarbo, J. (2015). A Foreign Policy Analysis Perspective on the Domestic Politics Turn in IR Theory. International Studies Review, 17(2), 189-216.

Kayhan-Pusane, Ö. (2017). Türkiye'nin Kuzey Irak Politikasında Değişim: Turgut Özal ve Tayyip Erdoğan Dönemleri Karşılaştırmalı Analizi. Uluslararası Iliş̧kiler, 14(56), 39-53.

Keohane, R. O. (1990). International Liberalism Reconsidered. J. Dunn (Ed.) The Economic Limits to Modern Politics içinde (s. 165-194). Cambridge: Cambridge University Press. 
Kılınç, R. (2000). Soğuk Savaş Sonrasında Basra Körfezinde Güvenlik: Yapılanma, AlgılamaIar, Politikalar. Avrasya Dosyası-Arap Dünyası Özel, 6(1), 6-27.

Laçinok, N. Y. (2007). Turgut Özal. Ali Faik Demir (yay. haz.). Türk Dış Politikasında Liderler: Süreklilik ve Değişim, Söylem ve Eylem içinde (s. 537-639). İstanbul: Bağlam Yayınları.

Locke, J. (1980). Second Treatise of Government. Indianapolis: Hackett Publishing.

Milliyet. (1986, 28 Şubat). Türkiye'den tam destek aldım, Arafat memnun.

Milliyet. (1988, 16 Kasım). Türkiye'den kutlama 'Filistin devleti hayırlı olsun'.

Milliyet. (1990, 13 Ekim). Bozer'den imalı istifa.

Milliyet. (1990, 4 Aralık). Uyarı gibi istifa.

Milliyet. (1992, 16 Nisan). Sezgin Şam'da Sert Çıktı.

Milliyet. (1992, 19 Nisan). Sezgin: "Bellerini Kırdık”.

Milliyet. (1995, 23 Mayıs). Musul'a ben engel oldum.

Moravcsik, A. (1992). Liberalism and International Relations Theory, Paper No. 92-6, Cambridge, Massachusetts: Harvard University.

--------. (2001). Liberal International Relations Theory: A Social Scientific Assessment, Cambridge, Massachusetts: Harvard University.

Olson, R. (2005). Türkiye-İran Ilişkileri 1979-2004: Devrim, İdeoloji, Savaş, Darbeler ve Jeopolitik. İstanbul: Ebabil Yayıncılık.

Oran, B. (2001). Dönemin Bilançosu. Baskın Oran (Ed.). Türk Dış Politikası: Kurtuluş Savaşından Bugüne Olgular, Belgeler, Yorumlar, Cilt:2, 1980-2001 içinde (s. 9-33). İstanbul: İletişim Yayınları.

Özal, T. (1984). Filistin Halkıyla Dayanışma Uluslararası Günü Sebebiyle Gönderilen Mesaj, 29 Kasım 1984. Başbakan Turgut Özal'ın Konuşma, Mesaj, Beyanat ve Mülakatları 13.12.1983-12.12.1984. Ankara: Başbakanlık Basımevi.

--------. (1985). Başbakan Turgut Özal'ın Konuşma, Mesaj, Beyanat ve Mülakatları. 13.12.1984-12.12.1985. Ankara: Başbakanlık Basımevi.

. (1991). Turkey in Europe and Europe in Turkey. Nicosia: Rüstem.

(1992). Türkiye’nin Önünde Hacet Kapıları Açılmıştır. Türkiye Günlüğü, 19, 5-23.

Özdemir, H. (2014). Turgut Özal. İstanbul: Doğan Kitap.

Özev, M. H. (2016). Siyasi, Ekonomik Çıkarlar ve Kimlik Politikaları Çerçevesinde 1929-2015 Arası Türkiye-Suudi Arabistan İliş̧kileri. Uluslararası Politik Araştırmalar Dergisi, 2(2), 11-28.

Özkan, T. (2004). CIA Kürtleri. İstanbul: Alfa Yayınları.

Paine, T. (1995). [1791]. The Rights of Man, New York: Oxford University Press.

Rawls, J. (1999). The Law of Peoples. Cambridge, MA: Harvard University Press.

Resmi Gazete (1987), https://www.resmigazete.gov.tr/arsiv/19660.pdf.

Ricardo, D. (1911). [1817]. The Principles of Political Economy and Taxation. London: London, J.M. Dent \& Sons; New York, E.P. Dutton \& Co.

Robins, P. (1991). Turkey and the Middle East. London: Royal Institute of International Affairs.

Rosecrance, R. N. (1986). The Rise of the Trading State. New York: Basic Books. 
Ruggie J. G. (Ed.). (1993). Multilateralism Matters: The Theory and Praxis of an Institutional Form. New York: Columbia University Press.

Russett, B. (2013). Liberalism. Tim Dunne, Milja Kurki ve Steve Smith (Der.). International Relations Theories: Discipline and Diversity içinde (s. 94-113). Oxford: Oxford University Press.

Sarıaslan, F. (2019). Filistin Sorunu ve Türkiye: Bir Denge Siyaseti. Filistin Araştırmaları Dergisi, 6, 1-32.

Sayarı, S. (1997). “Turkey and the Middle East in 1990's”, Journal of Palastine Studies, 26(3), 44-55.

Sinkaya, B. (2014). Türkiye’nin Devrim Sonrası İran ile İlişkileri. İdris Demir (Ed.). Türkiye’nin Dış Politikası: Yeni Eğilimleri, Yeni Yönelimleri Yeni Yaklaşımları içinde (s. 133-158). Bursa: Dora Yayıncilık.

Sorensen, G. (2006). Liberalism of Restraint and Liberalism of Imposition: Liberal Values and World Order in the New Millennium. International Relations, 20(3), 251-272.

Smith A. (2009). [1776]. The Wealth of Nations. Blacksburg: Thrifty Books.

Starr, P. (2007). Why Liberalism Works. The American Prospect, April 2007, 34-40.

Turan, ì. (1993). Ortadoğu'da Su Krizi ve Türkiye: Sorun ve Çözümler. İstanbul Üniversitesi Siyasal Bilgiler Fakültesi Dergisi, 3-4-5, 219-232.

Türkiye Cumhuriyeti Dışişleri Bakanlığı. Ekonomik İşbirliği Teşkilatı (EiT). http://www.mfa. gov.tr/ekonomik-isbirligi-teskilati-_eit_tr.mfa

Uslu, N. (2016). Çatlak İttifak: 1947’den Günümüze Türk-Amerikan İlişkileri. Ankara: Nobel Yayınları.

Yavuz, M. H. (2001). Değişen Türk Kimliği ve Dış Politika: Neo-Osmanlıcılığın Yükselişi. îhsan D. Dağı, Şaban H. Çalış ve Ramazan Gözen (Der.). Türkiye'nin Dış Politika Gündemi: Kimlik, Demokrasi, Güvenlik içinde (s. 35-63). Ankara: Liberte Yayınları.

Yavuzalp, E. (1996). Liderlerimiz ve Dış Politika. Ankara: Bilgi Yayınevi. 